\title{
ESTIMATING FISCAL MULTIPLIERS IN SELECTED ASIAN ECONOMIES
}

Roselle Dime, Edimon Ginting, and Juzhong Zhuang

NO. 638

August 2021
ADB ECONOMICS WORKING PAPER SERIES 


\section{ADB Economics Working Paper Series}

\section{Estimating Fiscal Multipliers in Selected Asian Economies}

Roselle Dime, Edimon Ginting, and Juzhong Zhuang

No. 638 | August 2021
Roselle Dime (roselle_dime@yahoo.com) is a consultant at the Asian Development Bank (ADB). Edimon Ginting (eginting@adb.org) is deputy director general of ADB's Economic Research and Regional Cooperation Department. Juzhong Zhuang (jzhuang1984@outlook.com) is adjunct professor at Fanhai International School of Finance of Fudan University, People's Republic of China. 
(C) 2021 Asian Development Bank

6 ADB Avenue, Mandaluyong City, 1550 Metro Manila, Philippines

Tel +632 8632 4444; Fax +63286362444

www.adb.org

Some rights reserved. Published in 2021.

ISSN 2313-6537 (print), 2313-6545 (electronic)

Publication Stock No. WPS210309-2

DOI: http://dx.doi.org/10.22617/WPS210309-2

The views expressed in this publication are those of the authors and do not necessarily reflect the views and policies of the Asian Development Bank (ADB) or its Board of Governors or the governments they represent.

ADB does not guarantee the accuracy of the data included in this publication and accepts no responsibility for any consequence of their use. The mention of specific companies or products of manufacturers does not imply that they are endorsed or recommended by ADB in preference to others of a similar nature that are not mentioned.

By making any designation of or reference to a particular territory or geographic area, or by using the term "country" in this document, $A D B$ does not intend to make any judgments as to the legal or other status of any territory or area.

This work is available under the Creative Commons Attribution 3.0 IGO license (CC BY 3.0 IGO)

https://creativecommons.org/licenses/by/3.0/igo/. By using the content of this publication, you agree to be bound by the terms of this license. For attribution, translations, adaptations, and permissions, please read the provisions and terms of use at https://www.adb.org/terms-use\#openaccess.

This CC license does not apply to non-ADB copyright materials in this publication. If the material is attributed to another source, please contact the copyright owner or publisher of that source for permission to reproduce it. $\mathrm{ADB}$ cannot be held liable for any claims that arise as a result of your use of the material.

Please contact pubsmarketing@adb.org if you have questions or comments with respect to content, or if you wish to obtain copyright permission for your intended use that does not fall within these terms, or for permission to use the ADB logo.

Corrigenda to ADB publications may be found at http://www.adb.org/publications/corrigenda.

Notes:

In this publication, “\$” refers to United States dollars.

ADB recognizes "China" as the People's Republic of China.

The ADB Economics Working Paper Series presents data, information, and/or findings from ongoing research and studies to encourage exchange of ideas and to elicit comment and feedback about development issues in Asia and the Pacific. Since papers in this series are intended for quick and easy dissemination, the content may or may not be fully edited and may later be modified for final publication. 


\section{CONTENTS}

TABLES AND FIGURES iv

$\begin{array}{lll}\text { ABSTRACT } & \mathbf{v}\end{array}$

$\begin{array}{lll}\text { I. INTRODUCTION } & 1\end{array}$

$\begin{array}{ll}\text { II. } & \text { LITERATURE REVIEW }\end{array}$

$\begin{array}{ll}\text { III. METHODOLOGY } & 4\end{array}$

$\begin{array}{lll}\text { IV. } & \text { DATA AND ESTIMATION }\end{array}$

$\begin{array}{llr}\text { V. DISCUSSIONS OF RESULTS } & 8\end{array}$

$\begin{array}{ll}\text { VI. SUMMARY AND CONCLUSIONS } & 10\end{array}$

$\begin{array}{ll}\text { APPENDIXES } & 12\end{array}$

1. List of Economies in the Panel Data 12

2. Impulse Responses 13

$\begin{array}{lr}\text { REFERENCES } & 25\end{array}$ 


\section{TABLES AND FIGURES}

\section{TABLES}

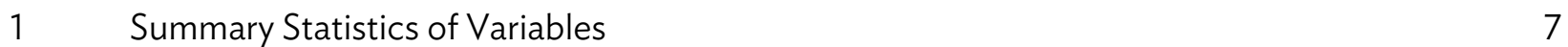

2 Fiscal Multiplier Estimates $\quad 9$

A1 Developing Asian Economies included in the Panel Data 12

\section{FIGURES}

1 COVID-19 Economic Stimulus Package in Selected Asian Economies 1

$\begin{array}{lll}\text { A2.1 Baseline Data } & 13\end{array}$

A2.2 Trade Openness-Government Spending 14

A2.3 Trade Openness-Tax $\quad 15$

A2.4 Financial Fragility-Government Spending 16

$\begin{array}{lll}\text { A2.5 } & \text { Fiscal Fragility-Tax } & 17\end{array}$

A2.6 Economic Cycle-Government Spending 18

A2.7 Economic Cycle-Tax 19

A2.8 Monetary Policy-Government Spending 20

A2.9 Monetary Policy-Tax 21

A2.10 Exchange Rate Policy-Government Spending 22

A2.11 Exchange Rate Policy-Tax 23 


\begin{abstract}
This paper estimates fiscal multipliers using quarterly data for a panel of nine developing Asian economies, following a vector autoregression model specification, but using local projections to extract the impulse responses. We provide evidence that the 4-quarter and 8-quarter cumulative multipliers for general government spending range between 0.73 and 0.88 in baseline estimations, in line with recently reported estimates for developed countries but larger than those for developing countries. We also find that the corresponding tax multipliers range between -0.41 and -0.62 , significantly smaller than recently reported estimates for developed countries but larger than those for developing countries. These results suggest that, without the stimulus measures introduced by countries around the world since the start of the COVID-19 pandemic, the global economy would have suffered even greater output loss.

This paper also shows evidence that an economy's structural and transitory characteristics can affect the size of fiscal multipliers. Economies that are less open to trade, have a lower level of debt, adopt a less flexible exchange rate, or maintain accommodative monetary policy have larger spending multipliers than those that are more open to trade, have a higher debt level, adopt a more flexible exchange rate, and maintain contractionary monetary policy. However, the business cycle appears to have little effect on the size of spending multipliers. We also find that the economies with a less flexible exchange rate have larger tax multipliers. But other structural and transitory characteristics appear to not have the expected effects on tax multipliers.
\end{abstract}

Keywords: fiscal multipliers, Asian economies, VAR models, COVID-19 pandemic

JEL codes: C32, E62, H50, O53 


\section{INTRODUCTION}

The coronavirus disease (COVID-19) pandemic has inflicted tremendous human, social, and economic pain on society at large worldwide. To protect people, jobs, and the economy from the devastating impacts of the pandemic, many governments have introduced various economic stimulus including fiscal measures ranging from tax cuts and wage subsidies to consumption coupons, cash transfers, and investment in capital and infrastructure (Figure 1). While most economies worldwide contracted in 2020, the unprecedented fiscal stimulus has naturally led to the question of how much gross domestic product (GDP) each dollar (or any other currency) worth of fiscal actions would generate, known as fiscal multipliers (Hepburn et al. 2020).

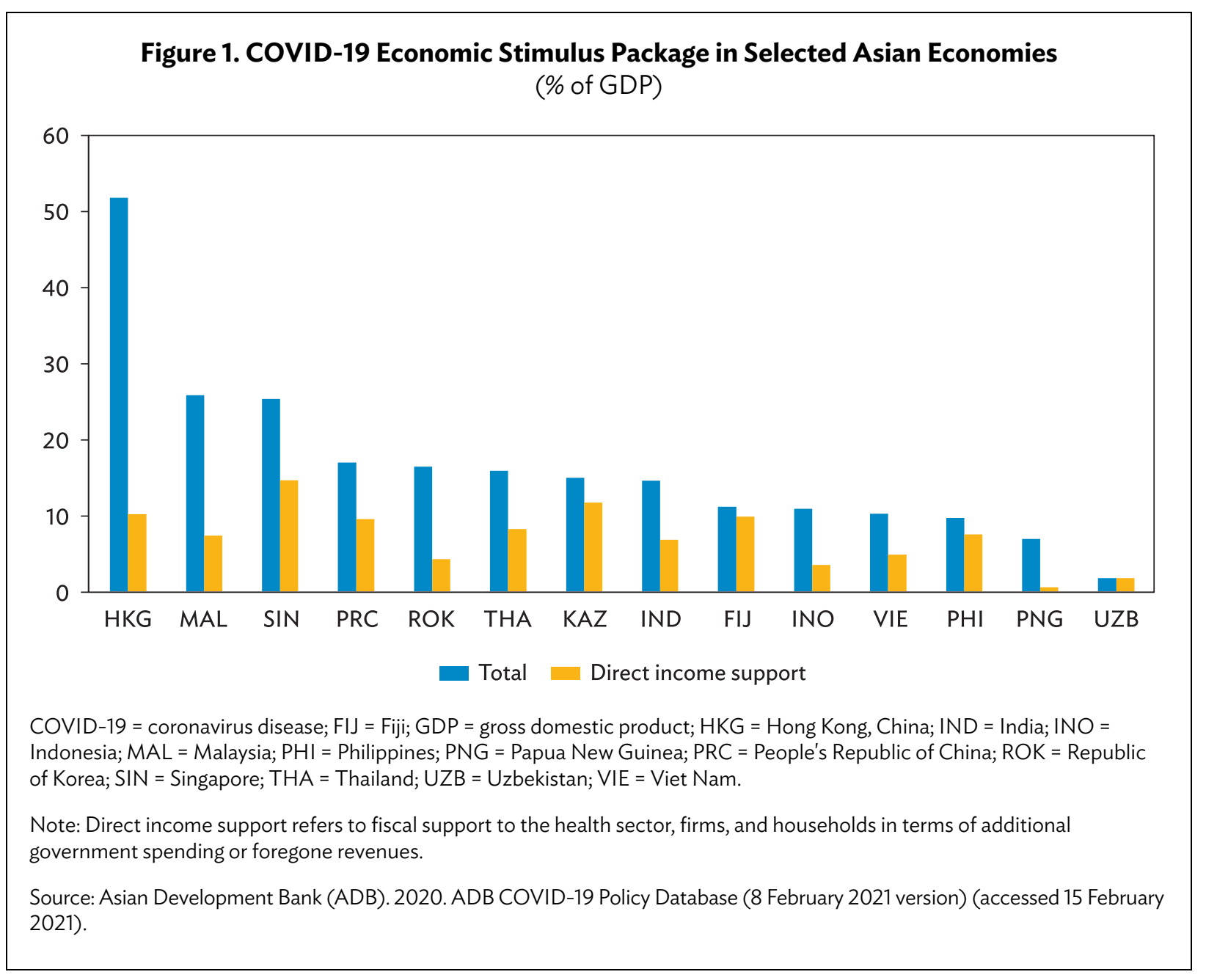

The fiscal multiplier is one of the most widely debated topics in macroeconomic policy discussions and empirical studies in recent years. After the 2008-2009 global financial crisis, many countries introduced large-scale fiscal stimulus to shore up their economic recovery; as public debt rapidly rose and the economy stabilized, their fiscal policy shifted from stimulus to consolidation. In this context, accurately measuring the relationship between output growth and fiscal policy actions was essential for effective economic policy management, planning, and forecasting. For example, 
Blanchard and Leigh (2013) found that the underestimation of fiscal multipliers early in the crisis contributed significantly to the growth forecast errors of the International Monetary Fund (IMF), with implications for policy making in the global economy and specific countries.

Empirical studies on fiscal multipliers have largely focused on developed countries, especially the United States (US) and Europe. Studies on developing countries have been relatively few because of the unavailability of a long-time series of high frequency data. In developing Asia, the available studies have produced mixed and inconclusive results. This paper aims to contribute to the still growing literature on fiscal multipliers in developing economies, focusing particularly on Asia. Specifically, we estimate fiscal multipliers using quarterly data from 2000 through to 2019 for a panel of nine developing Asian economies (Appendix 1 presents the list of these economies).

The rest of the paper is organized as follows: literature review (section 2), methodology (section 3), data and estimation (section 4), results (section 5), and summary and conclusions (section 6).

\section{LITERATURE REVIEW}

Fiscal multipliers measure the short-term impact of discretionary fiscal policy on output. They are usually defined as the ratio of a change in output to an exogenous change in government spending or tax with respect to their baselines. Economic theory predicts different sizes for fiscal multipliers, depending on which school of thought is considered.

Keynesian economics predicts larger fiscal multipliers than neoclassical economics. According to the standard Keynesian economic model, which sees consumers and producers slow to respond to price signals especially during economic downturns and recessions, government spending allows demand-constrained firms to boost output, raising economy-wide income and employment. Households then spend part of the higher income, which generates income and employment further. As this process continues, the cumulative impacts on output can drive fiscal multipliers to values greater than 1.0. In the case of tax cuts, the multiplier effects will be lower because, unlike government spending, which directly feeds into the economy and increases income, households may decide to save part of their income, therefore creating less new economic activity.

Neoclassical economics, on the other hand, downplays the importance of multiplier effects. According to the standard neoclassical model, which sees consumers and producers quick to respond to price signals, deficit spending requires the government to borrow, which may lead to higher interest rates, thus crowding out private investment and weakening the effects of fiscal policy. Another argument, known as the Ricardian equivalence (Barro 1996), claims that households may see higher government spending leading to higher future tax liability, which reduces their lifetime income. As a result, households may decide to reduce their current consumption, setting fiscal multipliers at zero. If households decide to work more, output will be higher, making fiscal multipliers positive; but they will be less than 1.0 because of the negative wealth effect on lifetime income that reduces current consumption.

Even within Keynesian economic models, different structural characteristics of the economy, such as trade openness, labor market rigidity, the size of automatic stabilizers, the exchange rate 
regime, the debt level, and public expenditure management, can lead to different predictions for fiscal multipliers (Batini et al. 2014). For example, less open countries tend to have higher fiscal multipliers because the demand leakage through imports is smaller. Wage rigidity can amplify the response of output to fiscal policy shocks. Exchange rate rigidity can also increase the size of fiscal multipliers because exchange rate movements may offset the impact of discretionary fiscal policy on the economy. On the other hand, countries with high levels of debt tend to have lower multiplier effects, as fiscal stimulus is likely to have negative credibility and confidence impacts on private demand and the interest rate risk premium. Automatic stabilizers such as taxes and transfers tend to reduce fiscal multipliers as they can offset part of the initial fiscal shocks. Multipliers are also expected to be smaller when difficulties to collect taxes and expenditure inefficiencies limit the impact of fiscal policy on output.

In addition to these structural characteristics, the size of fiscal multipliers also depends on some transitory factors that reflect the condition of the economy (Farhi and Werning 2016). One is the state of the business cycle. Fiscal multiplier effects are believed to be larger during recessions than during expansions - although, recent empirical studies show that tax multipliers are higher in absolute value during expansions than during recessions (Ramey 2019). A fiscal stimulus is likely to be less effective during the expansion stage because, at closer to full capacity, an increase in public demand can crowd out private demand. A fiscal consolidation is more costly in terms of output loss in a downturn because credit-constrained agents cannot borrow to smooth their consumption. It has also been noted that a downturn has a stronger effect on multipliers than an upturn, i.e., multipliers increase more in a recession than they decrease in an expansion (Batini et al. 2014).

Another important transitory factor that influences the size of fiscal multipliers is the degree of monetary accommodation to fiscal shocks. Expansionary monetary policy can cushion a fiscal stimulus package's upward impact on interest rates, thus avoiding or reducing the crowding-out effects and increasing the size of fiscal multipliers. In the case of fiscal consolidation, a lowering of interest rates can soften the impact on demand, making multipliers smaller. Recent works on the zero lower bound interest rates have also examined the monetary implication of a fiscal stimulus. In an environment where the nominal interest rates hit the zero lower bound, fiscal measures will be particularly effective since crowding out of investment from higher interest rates is largely absent, and the economy at this stage is likely to be operating at ample excess capacity (Woodford 2010; Christiano, Eichenbaum, and Rebelo 2011; Cloyne, Jorda, and Taylor 2020).

The empirical literature on fiscal multipliers is vast, and most studies focus on developed countries. A literature survey by Ramey (2019) found that most estimates of general government spending multipliers range from 0.6 to 0.8 or up to 1.0 , using either time series analysis (typically structural vector autoregression models of either a single country or panel of countries) or dynamic stochastic general equilibrium (DSGE) models. These estimates referred to cumulative multipliers over horizons between 0 and 20 quarters. The survey also noted the evidence of multipliers greater than 1.0 during recessions or times of slack, although considered not sufficiently robust, and being higher at times when monetary policy accommodates fiscal measures (such as during wartime or the period at the zero-lower bound). On the other hand, based on a survey of studies on the US, Whalen and Reichling (2015) reported that the 4-quarter cumulative multiplier of federal transfers to state and local governments for infrastructure investment can reach as high as 2.5. Findings of public investment having higher fiscal multipliers than general government spending are also confirmed by Alloza, Burriel, and Pérez (2018), who reported that the 4-quarter cumulative multiplier of public investment in the euro area is 1.91 and the 8 -quarter multiplier is 3.17 . 
Ramey (2019) also reported empirical estimates of the cumulative tax multipliers (the largest within the first 5 years) and found these are at least -2.0 to $-3.0,{ }^{1}$ much higher than the spending multipliers in absolute values, opposite to what the theory predicts. ${ }^{2}$ But Ramey noted that the tax multipliers estimated from DSGE models are typically below 1.0 and never higher than 1.5 (in absolute value). Similar findings were noted among empirical studies that, unlike spending multipliers which are countercyclical, tax multipliers are in fact procyclical, i.e., their absolute values are larger during expansions than during recessions.

While most empirical studies on fiscal multipliers have focused on developed countries, a few studies have made attempts in the context of developing countries. Compared with developed countries, there are reasons to predict that the size of fiscal multipliers for developing countries are larger, but there are also reasons to believe that these are smaller (Batini et al. 2014). The reasons for predicting larger fiscal multipliers for developing countries include greater liquidity constraints, less effective monetary policy responses and transmissions, lower automatic stabilizers, lower levels of public debt, and greater slacks in the economy (such as higher levels of unemployment and underemployment). The reasons for believing in smaller fiscal multipliers in developing countries include larger precautionary savings due to a more uncertain environment, less efficient management of public expenditure and revenue, lower creditability of fiscal policy due to higher interest rate spreads, and smaller and more open economies.

Batini et al. (2014) provided a survey of empirical studies on fiscal multipliers for developing countries, including those in Asia, Latin America and the Caribbean, the Middle East, Europe, and Africa. Most estimates of the first-year general government spending multipliers, including those of developing Asian economies, are in the range between 0.1 and 0.5 , either from single country studies or panel estimations. These are much smaller than the spending multipliers for developed countries. One notable exception is the estimate for the People's Republic of China (PRC), which is larger than 2.0, as reported by Wang and Wen (2013). Spending multipliers for oil-exporting countries were also found to be larger, i.e., close to 1.0. Similar to the findings for developed countries, the public investment multiplier was found to be greater than that of general government spending, as reported by Rafiq and Zeufack (2012) in the case of Malaysia: 2.7 during downturns and 2.0 during upturns. In the case of tax multipliers, the average absolute value of the estimates from about 20 studies surveyed is 0.26 , with more than half reporting zero value. Batini et al. (2014) also noted empirical findings that greater trade openness and more flexible exchange rates reduce fiscal multipliers.

\section{METHODOLOGY}

In this paper, we use vector autoregression (VAR) models and quarterly data of a panel of nine developing Asian economies to estimate fiscal multipliers (eight in the case of tax multipliers; see Appendix 1). The model specification follows Gechert and Mentges (2017) in using a bivariate setup to estimate the output (GDP) effects of fiscal policy (government spending and taxes) and Blanchard

1 Tax hikes discourage, whereas tax cuts stimulate, production or consumption. Economic theory predicts tax multipliers to have a negative sign.

2 The papers that produced large tax multipliers are more recent and mostly follow the narrative approach to identifying exogenous changes in fiscal policies. 
and Perotti (2002) in using four lags. ${ }^{3}$ We use the bivariate setup because of incomplete quarterly data for some Asian countries. The 4-quarter lags help to account for seasonal patterns of some variables, such as annual tax reporting on certain tax line items. Instead of estimating a VAR system, we estimate impulse responses by using local projections proposed by Jorda (2005). This avoids the need to impose any assumptions or restrictions on the VAR models for identification, since impulse responses of endogenous variables are directly obtained from the least square estimation of a single equation.

With this method, we estimate an equation using linear regression recursively over the horizon for which the impulse responses are being recovered. For each $h^{\text {th }}$ regression, the relevant coefficient of the variable considered as the impulse (either tax or government spending) is taken to represent the output response to a shock to the impulse variable for the $h^{\text {th }}$ horizon.

The cumulative impulse response equation of output from a tax shock for horizon $h$ is given by

$$
\Delta x_{j, t+h}=\alpha_{h}+\beta_{t x, h} t x_{j, t}+\sum_{i=1}^{4} \tau_{i, h} x_{j, t-i}+\sum_{i=1}^{4} \gamma_{i, h} t x_{j, t-i}+\varepsilon_{j, t+h}
$$

and, similarly, for a government spending shock

$$
\Delta x_{j, t+h}=\alpha_{h}+\beta_{g, h} g_{j, t}+\sum_{i=1}^{4} \tau_{i, h} x_{j, t-i}+\sum_{i=1}^{4} \rho_{i, h} g_{j, t-i}+\varepsilon_{j, t+h}
$$

where $\Delta x_{j, t+h}=x_{j, t+h}-x_{j, t} ; x_{j, t+h}$ is output of country $j$ at horizon $h ; x_{j, t}$ is output of country $j$ at period $t ; t x_{j, t}$ is tax revenue of country $j$ at period $t ; g_{j, t}$ is government spending of country $j$ at period $t$; and $\varepsilon_{j, t+h}$ is an independently and normally distributed disturbance term for the $h^{\text {th }}$ horizon equation. Each equation is estimated repeatedly $h$-times to obtain $\beta$-coefficients over the $h$ horizons for which the impulse response is to be generated.

It has been noted that local projections are more robust from the misspecification problem and are particularly useful when a VAR model is misspecified. Local projections also produce superior results compared with conventional VAR impulse responses when the sample size is relatively small. This method is, however, not without pitfalls; one of which is that it tends to produce more erratic results, particularly in longer time horizons such as more than 8 quarters (Plagborg-Moller and Wolf 2021). Our analysis focuses on 4-quarter and 8-quarter horizons.

To deal with endogeneity issues between government spending and output, we follow the assumption of Blanchard and Perotti (2002) that output has no contemporaneous effect on government spending and, hence, no endogeneity problems arise in the equation on output response from a spending shock. To control for endogeneity between tax and output, we use cyclically adjusted tax revenues to isolate discretionary tax policies; we then assume that output has no contemporaneous effects on tax since policy actions are likely to take more than 1 quarter to implement. ${ }^{4}$ Other approaches to addressing the endogeneity issues that have been developed are the natural experiment method (such as treating wars as a natural experiment and using war-induced government spending as an instrument) and the narrative method that tries to identify fiscal changes exogenous to the state of the economy. But these two approaches are not feasible for this paper.

3 We also tried to estimate impulse response equations using an optimal lag length, as specified by the Schwarz (1978) optimal lag length criterion, and obtained similar results as with the four-lag specification.

4 Tax policy, as indicated by the tax revenues, is composed of both the automatic component (which is a response to the economic cycle) and the cyclically adjusted component (i.e., discretionary fiscal policies). By using the cyclically adjusted component, the automatic response is taken out and only the discretionary component is considered (Elkhdari, Souissi, and Jewell 2018; David 2017; Tang, Liu, and Cheung 2010). 
We obtain the multiplier by dividing the impulse response by the average ratio of fiscal variable to output. The tax multiplier $\left(T M_{h}\right)$ and the government spending multiplier $\left(G M_{h}\right)$ for the $h^{\text {th }}$ quarter are given by

$$
T M_{h}=\beta_{t x, h} / \frac{t x}{x}
$$

and

$$
G M_{h}=\beta_{g, h} / \frac{g}{x}
$$

We extend the above baseline representations to examine if trade openness, the size of the debt burden, economic cycles, the exchange rate regime, and the conduct of monetary policy affect the size of the multiplier. To do this, we use the threshold regression method, following Baum and Koester (2011); Ferraresi, Roventini, and Fagiolo (2013); Ramey and Zubairy (2018); and Shaheen and Turner (2020). The method involves defining a threshold (regime) variable (among the list above) and conditional variable (i.e., an independent variable whose coefficient is conditional on the threshold variable). The conditional variable here is either tax or government spending. The threshold regression finds the value of the threshold variable where the coefficient of the shock term (indicated by $\beta$ ) changes by minimizing the sum of squares residuals from the least squares estimation of the impulse response equation of output.

Thus, the output equations to be estimated are re-specified by making the "shock" term regime dependent.

$$
\begin{gathered}
\Delta x_{j, t+h}=\alpha_{h}+I_{j, t-1} \beta_{t x, h}^{r 1} t x_{j, t}+\left(1-I_{j, t-1}\right) \beta_{t x, h}^{r 2} t x_{j, t} \\
+\sum_{i=1}^{4} \tau_{i, h} x_{j, t-i}+\sum_{i=1}^{4} \gamma_{i, h} t x_{j, t-i}+\varepsilon_{j, t+h} \\
\Delta x_{j, t+h}=\alpha_{h}+I_{j, t-1} \beta_{g, h}^{r 1} g_{t}+\left(1-I_{j, t-1}\right) \beta_{g, h}^{r 2} g_{j, t} \\
+\sum_{i=1}^{4} \tau_{i, h} x_{j, t-i}+\sum_{i=1}^{4} \rho_{i, h} g_{j, t-i}+\varepsilon_{j, t+h}
\end{gathered}
$$

where $I$ is a dummy variable for the regime the economy is in when the shock hits, defined by

$$
I_{j, t-1}=\left\{\begin{array}{l}
1 \text { if }\left(q_{j t}<\gamma\right) \\
0 \text { if }\left(q_{j t} \geq \gamma\right)
\end{array}\right\}
$$

where $q_{j, t}$ is the regime-defining variable and $\gamma$ is a threshold value. We use GDP, money market rate, and nominal exchange rate movements as $q_{j t}$ to account for the effects of economic cycles, monetary policy stance, and exchange rate regimes on fiscal multipliers.

However, we employ predefined dummy variables to account for the effects of trade openness and debt fragility regimes on fiscal multipliers because of incomplete quarterly trade and debt data. We apply the trade-to-GDP ratio of $60 \%$ as the threshold, whereby countries with a ratio higher than $60 \%$ are classified as "open" economies and those with a ratio lower than $60 \%$ are classified as "closed" economies. Similarly, we group sample countries into two with differing fiscal fragility according to whether their public debt-to-GDP ratio is greater or smaller than $60 \%$ for 3 consecutive years. 


\section{DATA AND ESTIMATION}

We use a balanced panel of nine developing Asian economies (eight in the case of tax multipliers), with data from 2000 through to 2019 in estimating fiscal multipliers. GDP, GDP deflator, and government spending data are obtained from CEIC. 5 Tax revenue data are from CEIC, and population data are from the United Nations (UN) World Population Prospects (UN DESA 2019). Money market rates and nominal exchange rates, which are used as threshold variables, are from CEIC and the IMF's International Financial Statistics Database. ${ }^{6}$ Trade data are from the UN Conference on Trade and Development, and debt data from the IMF's Public Debt Database.7 GDP, government spending, and tax revenue are quarterly data; money market rates and nominal exchange rates are quarterly averages of monthly data; and the trade-to-GDP ratio (openness), debt-to-GDP ratio (fiscal fragility), and population are annual data.

Government spending consists of expenditure on consumption and investment. Tax revenue is not net of transfers because quarterly transfer data for some economies are not available. All the endogenous variables are expressed in real per capita and logarithmic terms and are seasonally adjusted. GDP and government spending data are obtained in constant prices. For tax revenue, we convert the nominal values to real terms using the GDP deflator. Table 1 provides the descriptive statistics of these variables.

Each series was checked for the presence of unit root and was found to be nonstationary. To deal with the nonstationarity, we checked for the appropriate trend component to use and established the presence of a deterministic trend. We thus used two equation specifications, one with a quadratic trend and the other with both a linear and a quadratic trend term, following the common practice in the literature.

Table 1: Summary Statistics of Variables

\begin{tabular}{lccccc}
\hline Variable & $\begin{array}{c}\text { Number of } \\
\text { Observations }\end{array}$ & Mean & $\begin{array}{c}\text { Standard } \\
\text { Deviation }\end{array}$ & Minimum & Maximum \\
\hline Government Spending Panel & & & & & \\
\hline Log (real GDP per capita) & 760 & 10.8 & 2.1 & 8.3 & 16.1 \\
Log (real GE per capita) & 760 & 8.7 & 2.0 & 6.1 & 13.6 \\
Exchange rate movement & 760 & 7.5 & 21.8 & 0.0 & 405.1 \\
$\quad$ (absolute value of \% change) & 760 & 4.3 & 6.2 & 0.04 & 74.2 \\
Money market rate (\%) & 760 & 0.9 & 0.3 & 0.0 & 1.0 \\
Dummy for trade openness & 760 & 0.2 & 0.4 & 0.0 & 1.0 \\
Dummy for financial fragility & & & & & continued on next page
\end{tabular}

CEIC Data. Global Database. https://www.ceicdata.com/en (accessed May 2020).

6 IMF. International Financial Statistics Database. https://data.imf.org/?sk=4c514d48-b6ba-49ed-8ab9-52b0c1a0179b (accessed May 2020).

7 United Nations Conference on Trade and Development (UNCTAD). UNCTADStat Database. http://unctadstat.unctad.org/wds (accessed May 2020); and IMF. IMF Public Debt Database. https://www.imf.org/external/datamapper/datasets/DEBT (accessed May 2020). 
Table 1 continued

\begin{tabular}{lccccc}
\hline Variable & $\begin{array}{c}\text { Number of } \\
\text { Observations }\end{array}$ & Mean & $\begin{array}{c}\text { Standard } \\
\text { Deviation }\end{array}$ & Minimum & Maximum \\
\hline Tax Panel & & & & & \\
\hline Log (real GDP per capita) & 559 & 10.0 & 1.2 & 7.6 & 12.2 \\
Log (real tax revenue per capita) & 558 & 7.9 & 0.8 & 5.8 & 9.4 \\
Exchange rate movement & 560 & 4.0 & 4.9 & 0.0 & 47.7 \\
$\quad$ (absolute value of \% change) & 560 & 2.7 & 2.1 & 0.04 & 14.4 \\
Money market rate (\%) & 560 & 0.9 & 0.4 & 0.0 & 1.0 \\
Dummy for trade openness & 560 & 0.2 & 0.4 & 0.0 & 1.0 \\
Dummy for financial fragility & 58.0 & & & \\
\hline
\end{tabular}

$\mathrm{GDP}=$ gross domestic product, $\mathrm{GE}=$ government spending.

Source: Authors' calculations.

\section{DISCUSSIONS OF RESULTS}

Table 2 reports estimates of 4-quarter and 8-quarter cumulative multipliers, based on the two trend specifications for government spending and tax revenue, for the baseline (that does not consider any possible regime shifts) as well as various alternatives that allow for regime shifts in trade openness, debt fragility, economic cycle, monetary policy stance, and exchange rate system. Appendix 2 presents charts of the impulse responses used to derive the multipliers. A number of observations can be made.

First, the two trend specifications produce different results, with the size of multipliers greater for the quadratic trend specification (Columns 1 and 3 ) than the linear and quadratic trend specification (Columns 2 and 4), in most cases.

Second, focusing on the quadratic trend specification, the baseline estimates of the 4-quarter cumulative government spending multiplier is 0.73 and the 8 -quarter cumulative multiplier is 0.88 ; both are smaller than 1.0, but having an expected sign and being statistically significant at the 5\% confidence level. These results are in line with the findings highlighted in Ramey (2019) for developed countries, but greater than those reported in Batini et al. (2014) for developing economies (see discussions in section 2). For the baseline estimates of tax multiplier, the 4-quarter cumulative multiplier is -0.41 and the 8 -quarter cumulative multiplier is -0.62 ; both are smaller than 1.0 in absolute value, but have an expected sign and are significant at 5\%. These are much smaller than the corresponding multipliers for developed countries, but greater than those for developing economies, as reported in Ramey (2019) and Batini et al. (2014).

Third, many of the regime shifts have expected effects on the size of multipliers, although not all. Still focusing on the quadratic trend specification, in the case of government spending, the cumulative multipliers for closed economies are estimated at 0.9 (4-quarter multiplier) and 1.26 (8-quarter multiplier); while, for open economies, these two multipliers are much smaller and statistically insignificant. The 4-quarter and 8-quarter cumulative spending multipliers are more or less the same in value for both low-debt and high-debt economies, but the 8-quarter multiplier is statistically insignificant for high-debt economies. Although the two multipliers for economies with a 
controlled exchange rate regime are only slightly larger than those with a flexible exchange rate regime, these are statistically insignificant for economies with a flexible exchange rate regime.

\section{Table 2: Fiscal Multiplier Estimates}

\begin{tabular}{|c|c|c|c|c|}
\hline \multirow[b]{2}{*}{ Regime } & \multicolumn{2}{|c|}{ Spending Multiplier } & \multicolumn{2}{|c|}{ Tax Multiplier } \\
\hline & $\begin{array}{c}\text { Quadratic Trend } \\
\text { (1) }\end{array}$ & $\begin{array}{l}\text { Quadratic and } \\
\text { Linear Trend } \\
\text { (2) }\end{array}$ & $\begin{array}{l}\text { Quadratic Trend } \\
\text { (3) }\end{array}$ & $\begin{array}{c}\text { Quadratic and } \\
\text { Linear Trend } \\
\text { (4) }\end{array}$ \\
\hline \multicolumn{5}{|l|}{ Baseline } \\
\hline 4-quarter & $0.73^{*}$ & $0.46^{*}$ & $-0.41^{*}$ & $-0.39^{*}$ \\
\hline 8-quarter & $0.88^{*}$ & $0.49^{*}$ & $-0.62^{*}$ & $-0.60^{*}$ \\
\hline \multicolumn{5}{|c|}{ Closed Economy } \\
\hline 4-quarter & $0.90^{*}$ & $0.88^{*}$ & $-0.15^{*}$ & $-0.11^{*}$ \\
\hline 8-quarter & $1.26^{*}$ & $1.15^{*}$ & $-0.19^{*}$ & $-0.17^{*}$ \\
\hline \multicolumn{5}{|c|}{ Open Economy } \\
\hline 4-quarter & 0.58 & $-0.01^{*}$ & $-0.55^{*}$ & $-0.55^{*}$ \\
\hline 8 quarter & 0.56 & $-0.25^{*}$ & $-0.87^{*}$ & $-0.85^{*}$ \\
\hline \multicolumn{5}{|l|}{ Low Debt } \\
\hline 4-quarter & $0.70^{*}$ & $0.45^{*}$ & $-0.31^{*}$ & $-0.29^{*}$ \\
\hline 8-quarter & $0.85^{*}$ & $0.48^{*}$ & $-0.45^{*}$ & $-0.42^{*}$ \\
\hline \multicolumn{5}{|l|}{ High Debt } \\
\hline 4-quarter & $0.71^{*}$ & 0.46 & $-1.40^{*}$ & $-1.43^{*}$ \\
\hline 8-quarter & 0.86 & 0.48 & $-2.44^{*}$ & $-2.44^{*}$ \\
\hline \multicolumn{5}{|c|}{ Economic Downturn } \\
\hline 4-quarter & $0.78^{*}$ & 0.23 & $-0.29^{*}$ & $-0.28^{*}$ \\
\hline 8-quarter & $0.94^{*}$ & 0.29 & $-0.15^{*}$ & $-0.14^{*}$ \\
\hline \multicolumn{5}{|c|}{ Economic Upturn } \\
\hline 4-quarter & $0.81^{*}$ & 0.25 & $-1.12^{*}$ & $-1.12^{*}$ \\
\hline 8-quarter & $0.99^{*}$ & 0.23 & $-0.96^{*}$ & $-0.97^{*}$ \\
\hline \multicolumn{5}{|c|}{ Accommodative Monetary Policy } \\
\hline 4-quarter & $0.62^{*}$ & 0.26 & $-0.68^{*}$ & $-0.68^{*}$ \\
\hline 8 -quarter & $1.00^{*}$ & 0.27 & 0.98 & 1.11 \\
\hline \multicolumn{5}{|c|}{ Contractionary Monetary Policy } \\
\hline 4-quarter & $0.55^{*}$ & 0.23 & -0.16 & -0.15 \\
\hline 8-quarter & $0.95^{*}$ & 0.24 & -0.55 & $-0.55^{*}$ \\
\hline \multicolumn{5}{|c|}{ Controlled Exchange Rate } \\
\hline 4-quarter & $0.47^{*}$ & 0.34 & $-0.98^{*}$ & $-0.94^{*}$ \\
\hline 8-quarter & $0.63^{*}$ & 0.40 & $-2.65^{*}$ & $-2.76^{*}$ \\
\hline \multicolumn{5}{|c|}{ Flexible Exchange Rate } \\
\hline 4-quarter & 0.39 & 0.29 & $-0.33^{*}$ & $-0.32^{*}$ \\
\hline 8-quarter & 0.56 & 0.36 & $-0.53^{*}$ & $-0.54^{*}$ \\
\hline
\end{tabular}

Note: Numbers marked with “*”) indicate significance at the $5 \%$ level.

Source: Authors' calculations. 
Finally, while the 4-quarter and 8-quarter cumulative spending multipliers are statistically significant for both economies with accommodative and contractionary monetary policies, these are larger for economies with accommodative policies, although only slightly. These results support the arguments that trade openness, fiscal fragility, and exchange rate flexibility reduce the size of government spending multipliers, while monetary accommodation increases them. However, the business cycle appears to have no significant effect on the two spending multipliers, being statistically significant for both economies in upturns and downturns and, in fact, slightly larger for economic upturns than economic downturns.

The effects of the regime shift on tax multipliers are more mixed. Economies that are more open and with higher debt levels have 4-quarter and 8-quarter cumulative tax multipliers that are both larger in absolute values than those economies that are less open and with lower debt levels. These results are contrary to what is expected. In fact, for high-debt economies, the 4-quarter multiplier is 1.40 and the 8 -quarter multiplier is -2.44 , which are significantly larger than 1.0 . In contrast, the cumulative tax multipliers for low-debt economies are -0.31 (4-quarter multiplier) and -0.45 (8quarter multiplier). The two multipliers are larger in absolute values for economies in upturns than those in downturns, again opposite to what is expected, but consistent with recent empirical findings as highlighted in Ramey (2019). Further, the monetary policy stance appears to have little effect on the size of tax multipliers. On the other hand, the 4-quarter multiplier is -0.98 and the 8-quarter multiplier is -2.65 for economies with a controlled exchange rate regime. These are far larger in absolute values than the multipliers for economies with a flexible exchange rate regime, consistent with what the theory predicts and empirical findings highlighted in Batini et al. (2014).

\section{SUMMARY AND CONCLUSIONS}

This paper attempts to estimate the effects of fiscal policy measures (whether stimulus or consolidation) on output using a panel of nine developing Asian economies. The methodology follows a VAR model specification similar to that of Blanchard and Perotti (2002), but uses local projections proposed by Jorda (2005) to extract impulse responses and compute the fiscal multipliers. The key results can be summarized as follows.

First, the 4-quarter and 8-quarter cumulative government spending multipliers range between 0.73 and 0.88 in the baseline of the preferred model specification (with a quadratic trend), with the estimates being statistically significant at $5 \%$ level in both cases. These estimates are in line with the existing findings for developed countries that are based on time series analyses; however, they are significantly larger than what the literature has reported for developing countries, including those that are based on the data of the Asian economies (e.g., Tang, Liu, and Cheung 2010). The fact that the spending multipliers are smaller than 1.0 suggests some crowding-out effects of the fiscal stimulus.

Second, the 4-quarter and 8-quarter baseline cumulative tax multipliers are estimated to range between -0.41 and -0.62 , both being statistically significant at $5 \%$ level. These estimates are again larger than those reported for developing countries, but are much smaller in absolute values compared with the empirical findings for developed countries recently reported in the literature.

Third, controlling for regime shift provides some evidence that the size of the spending multiplier depends on structural and transitory characteristics of the economy as expected. Economies 
that are more open to trade, have a higher level of debt, or adopt a more flexible exchange rate have smaller or statistically insignificant spending multipliers compared with those that are less open to trade, have a lower debt level, or adopt a less flexible exchange rate. For instance, the 8-quarter spending multiplier is 1.26 for closed economies, while it is statistically insignificant for open economies. We also find the spending multipliers to be larger when the monetary policy is accommodative than when it is contractionary, although only slightly. However, the business cycle appears to have little effect on the size of the spending multipliers.

On the other hand, the effects of regime shift on the tax multipliers are more mixed. Trade openness and fiscal fragility affect the tax multipliers in the opposite way than expected. The tax multipliers are larger during economic upturns than during downturns; these are also contrary to what is expected, although consistent with recent empirical findings reported in the literature. Monetary policy stance appears to have little effect on the tax multipliers. Only the exchange rate flexibility had the expected effect, with the 4-quarter cumulative tax multiplier calculated at -0.98 and the 8 -quarter multiplier at -2.65 for economies with a controlled exchange rate regime, compared with -0.33 (4-quarter multiplier) and -0.53 (8-quarter multiplier) for economies with a flexible exchange rate regime.

The different results of this study from the existing empirical findings on developing Asian economies could be partly attributed to the use of a longer time period in the sample. But the sample size of this study is still small, involving only nine economies for the spending multipliers and eight economies for the tax multipliers. Clearly, more careful studies are needed to better understand how fiscal policy measures affect output.

The launch of large fiscal stimulus packages by countries all over the world to support businesses, households, and economic recovery since the start of the COVID-19 pandemic in 2020 has raised significant interest in understanding how these stimulus measures will affect output. Our empirical findings on fiscal multipliers suggest that government spending and tax cuts can boost output, although not to the extent as Keynesian economic theory has postulated. Further, government spending is more effective than tax cuts, and monetary policy accommodation can make the fiscal measures more effective. These results also suggest that, without the stimulus measures, countries would have suffered even greater output losses because of the pandemic. 


\section{APPENDIXES}

\section{Appendix 1: List of Economies in the Panel Data}

This section presents the dynamic panel estimation results for a sample of 15 emerging market economies comprising Brazil, Chile, Colombia, the Czech Republic, Hungary, India, Indonesia, Malaysia, the People's Republic of China, the Philippines, Poland, the Republic of Korea, Singapore, South Africa, and Thailand $(\mathrm{N}=15, \mathrm{~T}=131)$. The results provide further support to the empirical findings for emerging Asian economies discussed in the main text.

\section{Table A1. Developing Asian Economies included in the Panel Data}

\begin{tabular}{lll}
\hline Government Spending & \multicolumn{1}{c}{ Tax } \\
\hline 1. Hong Kong, China & 1. China, People's Republic of \\
2. India & 2. Hong Kong, China \\
3. Indonesia & 3. India \\
4. Korea, Republic of & 4. Korea, Republic of \\
5. Malaysia & 5. Malaysia \\
6. Philippines & 6. Philippines \\
7. Singapore & 7. Singapore \\
8. Taipei,China & 8. Taipei,China \\
9. Thailand & \\
\hline
\end{tabular}

Source: Authors. 


\section{Appendix 2: Cumulative Impulse Responses}

\section{Figure A2.1: Baseline Data}

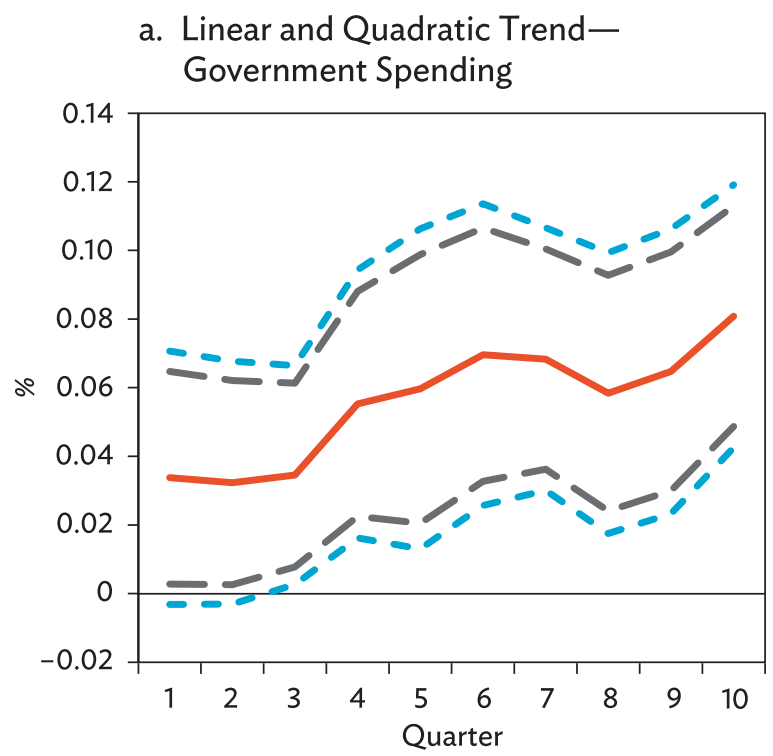

b. Quadratic Trend-

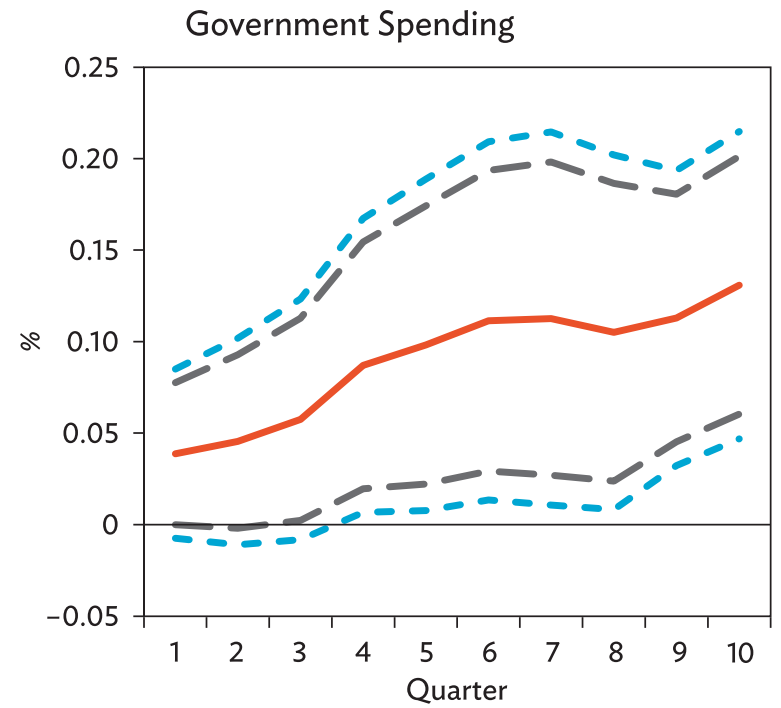

c. Linear and Quadratic Trend-Tax

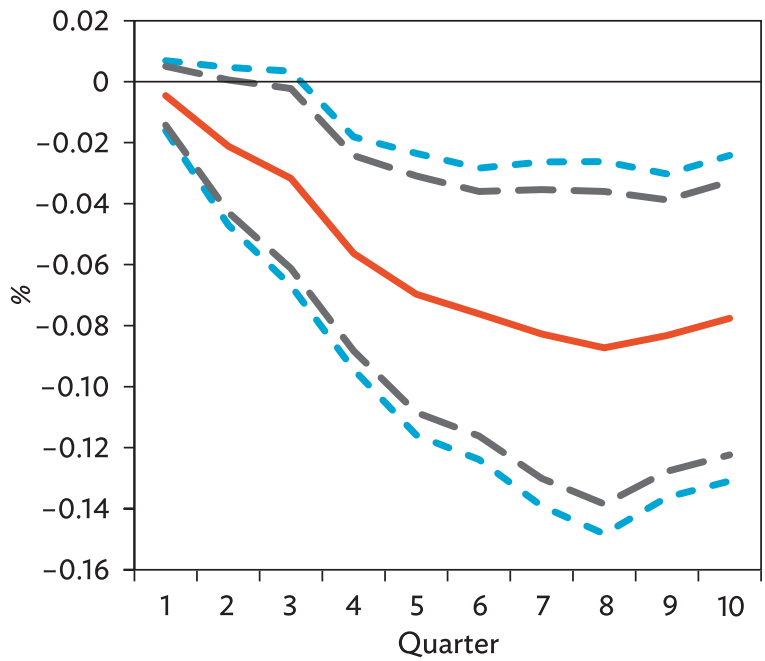

d. Quadratic Trend-Tax

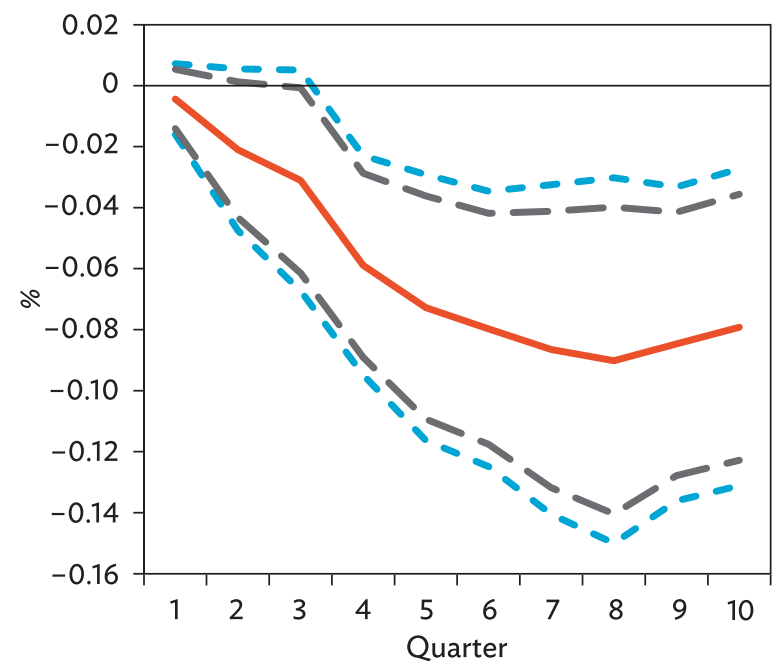

- IRF bands at $5 \%$ level of significance

- IRF bands at $10 \%$ level of significance

Impulse response

IRF = impulse response function.

Source: Authors' estimation. 


\section{Figure A2.2: Trade Openness-Government Spending}

a. Linear and Quadratic TrendClosed Economy

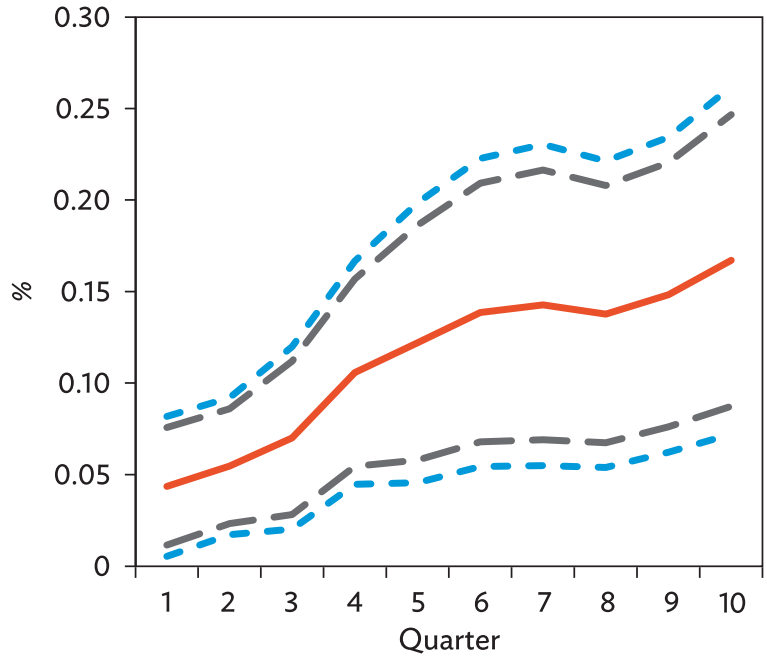

c. Quadratic Trend-Closed Economy

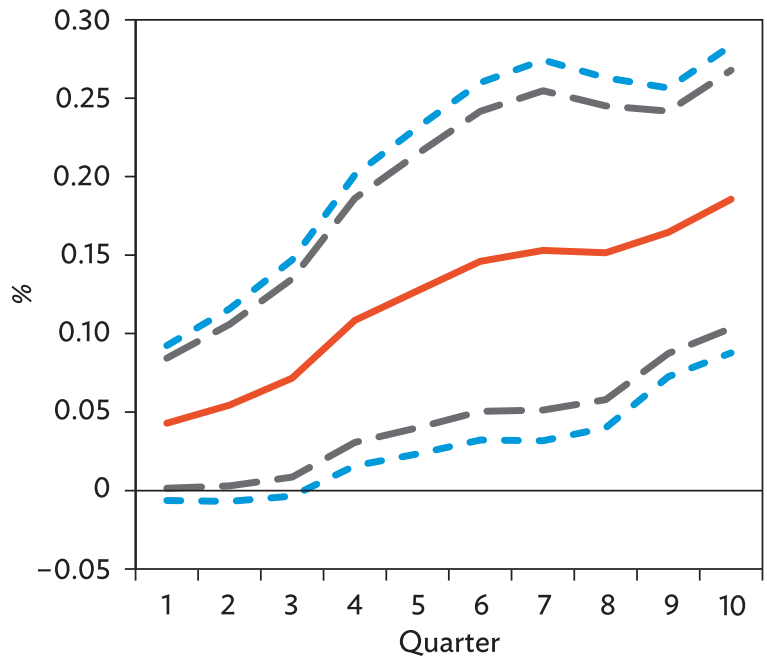

b. Linear and Quadratic TrendOpen Economy

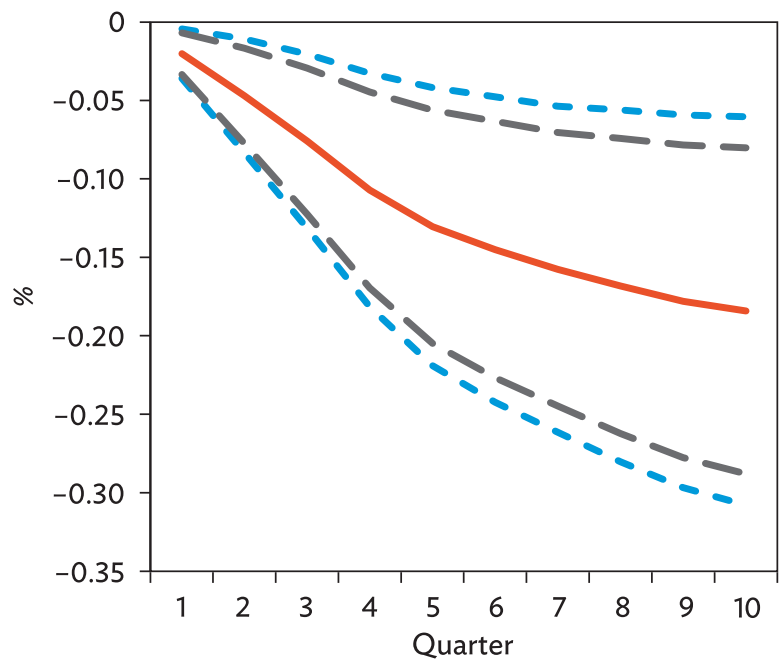

d. Quadratic Trend-Open Economy

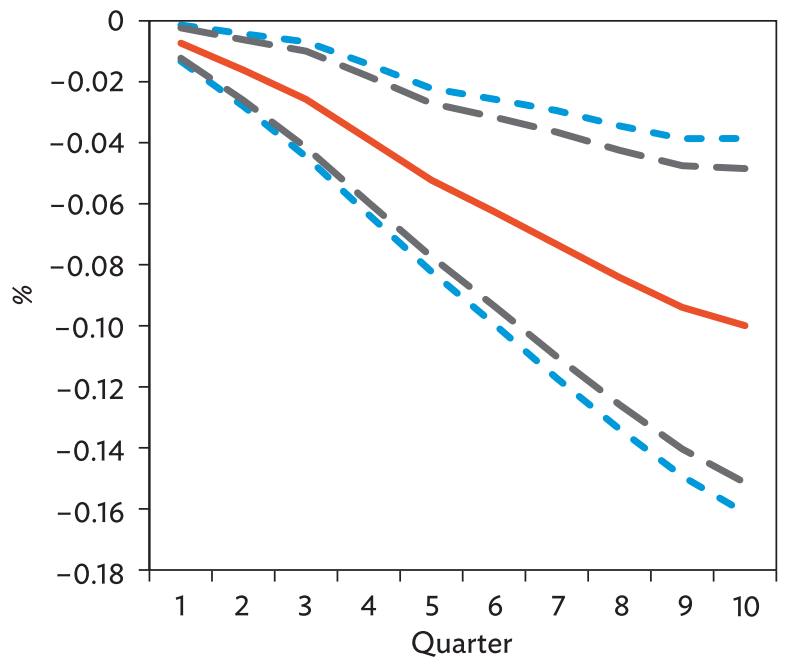

- - IRF bands at $5 \%$ level of significance

Impulse response

— IRF bands at $10 \%$ level of significance

$\mathrm{IRF}=$ impulse response function.

Source: Authors' estimation. 
Figure A2.3: Trade Openness-Tax

a. Linear and Quadratic TrendClosed Economy

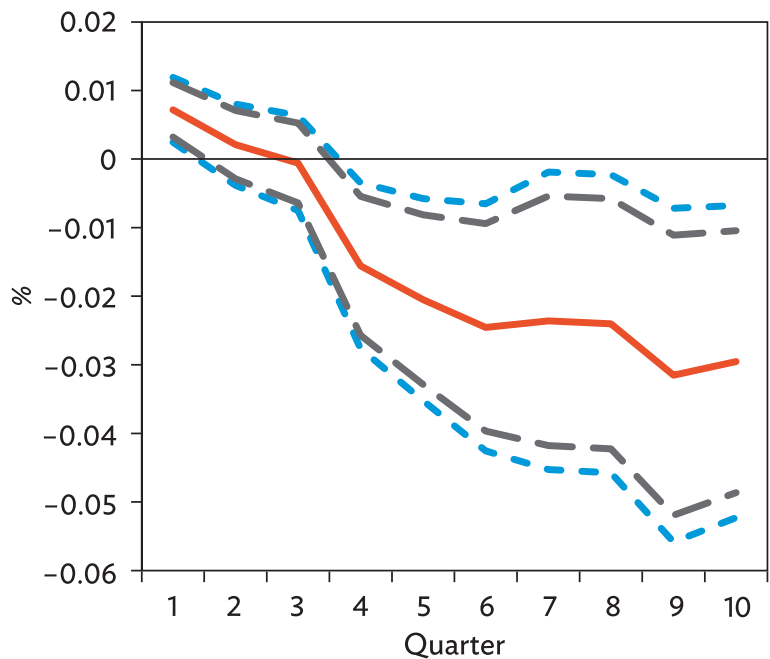

c. Quadratic Trend-Closed Economy

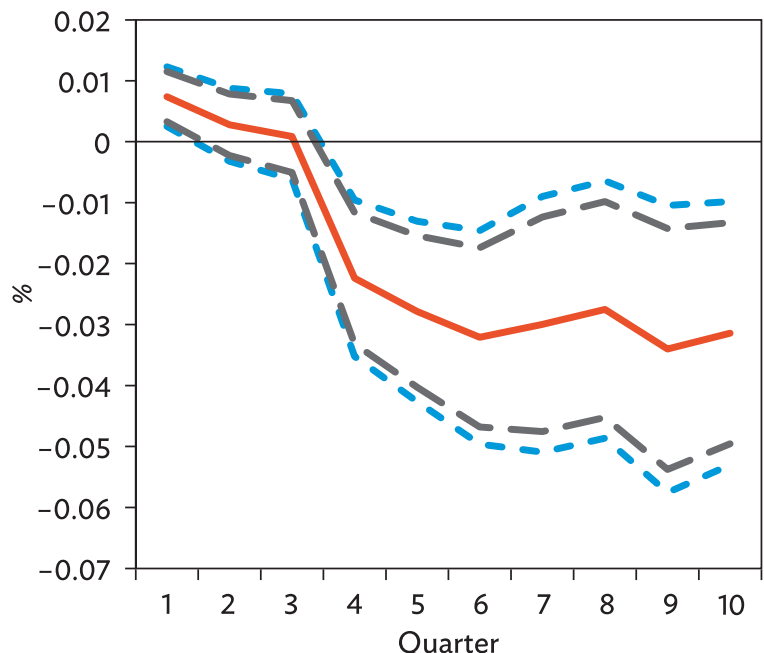

b. Linear and Quadratic TrendOpen Economy

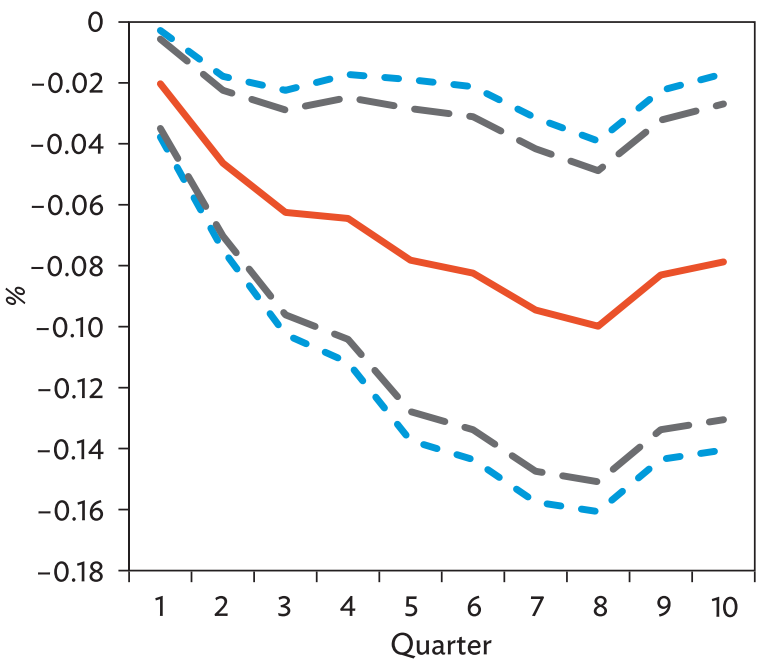

d. Quadratic Trend-Open Economy

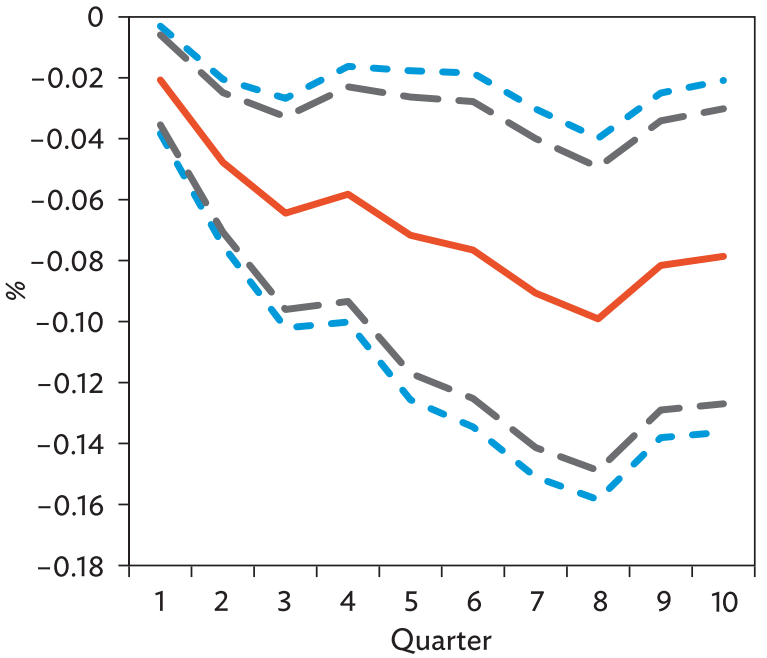

Impulse response

- IRF bands at $5 \%$ level of significance

- IRF bands at $10 \%$ level of significance

$\mathrm{IRF}=$ impulse response function.

Source: Authors' estimation. 


\section{Figure A2.4: Financial Fragility-Government Spending}

a. Linear and Quadratic Trend-Low Debt

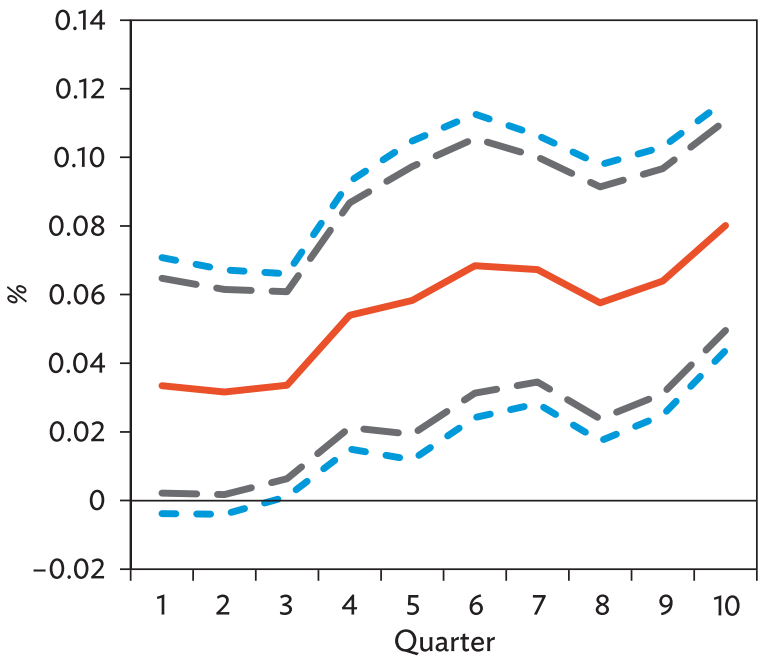

c. Quadratic Trend-Low Debt

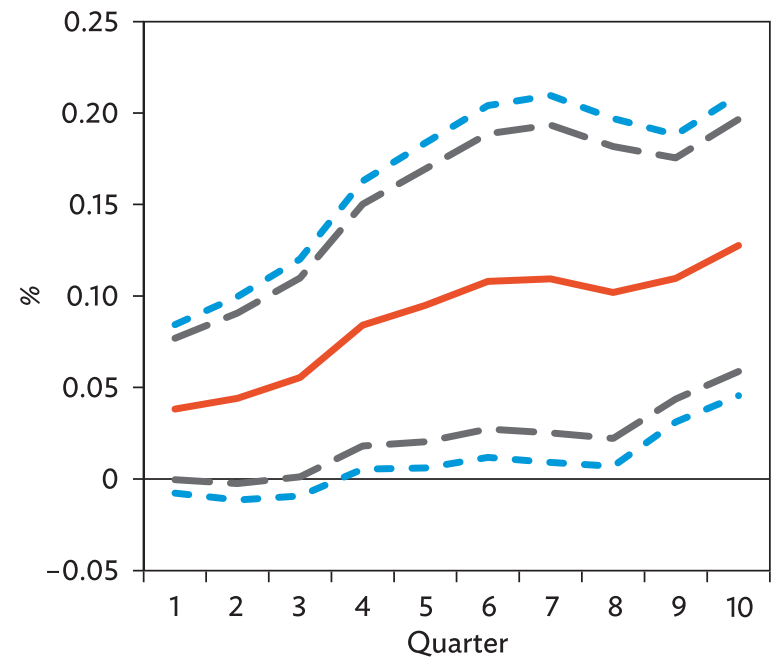

- - IRF bands at $5 \%$ level of significance

- IRF bands at $10 \%$ level of significance b. Linear and Quadratic Trend-High Debt

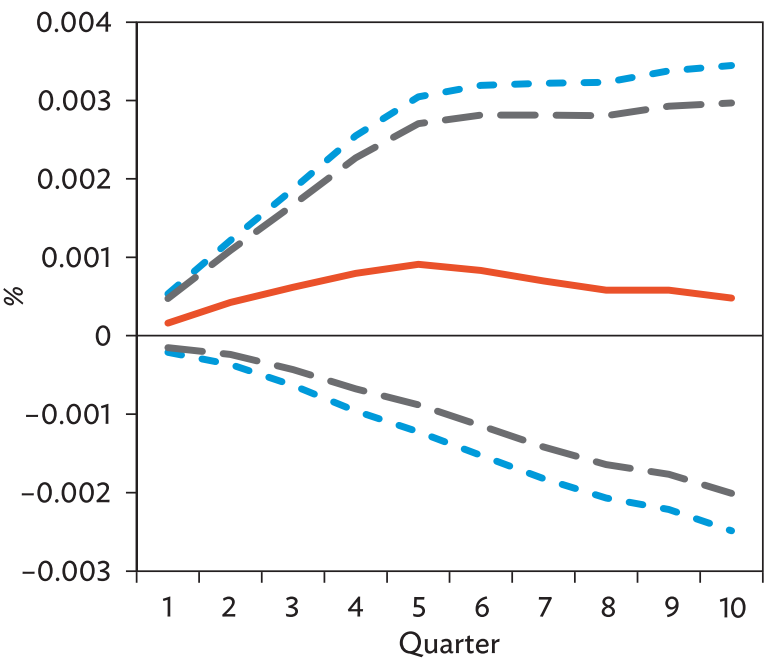

d. Quadratic Trend-High Debt

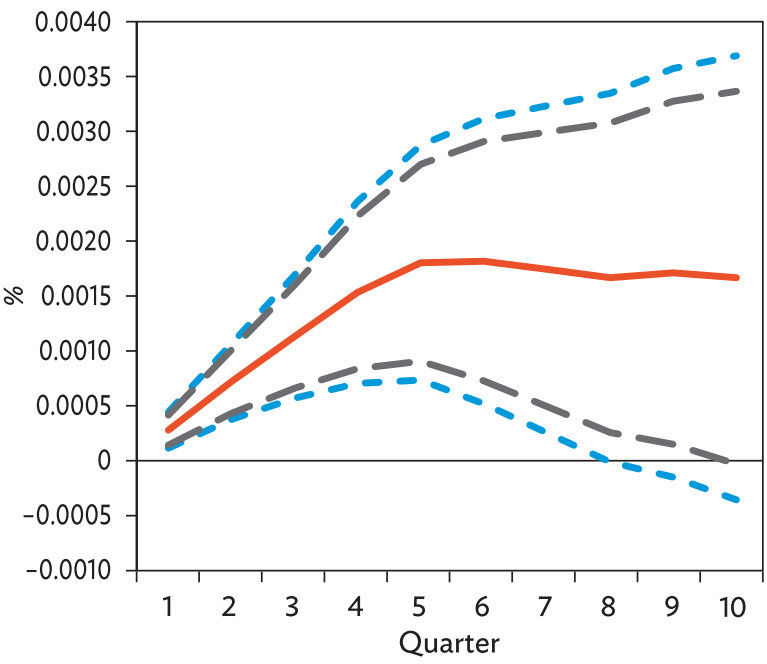

Impulse response

IRF = impulse response function.

Source: Authors' estimation. 


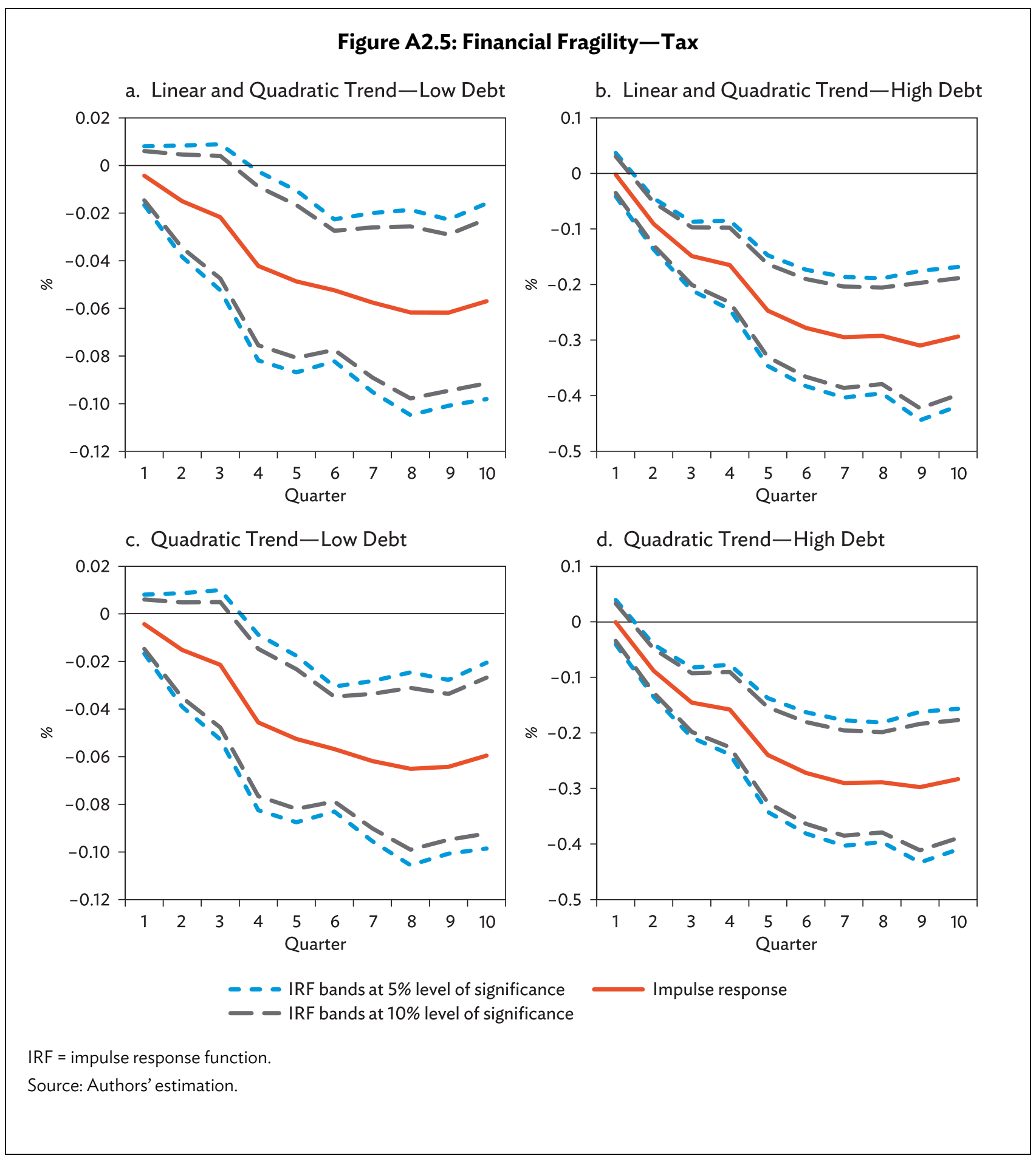




\section{Figure A2.6: Economic Cycle-Government Spending}

a. Linear and Quadratic Trend-Downturn

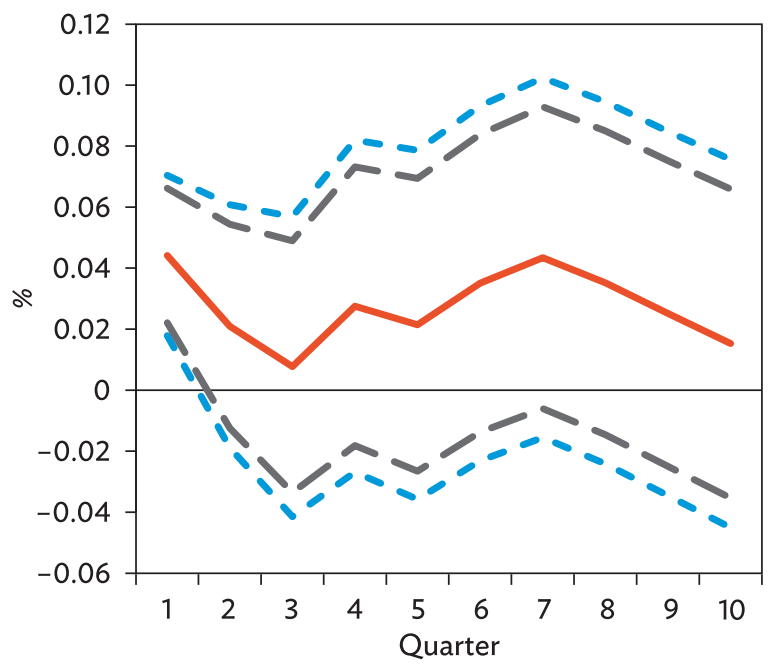

c. Quadratic Trend-Downturn

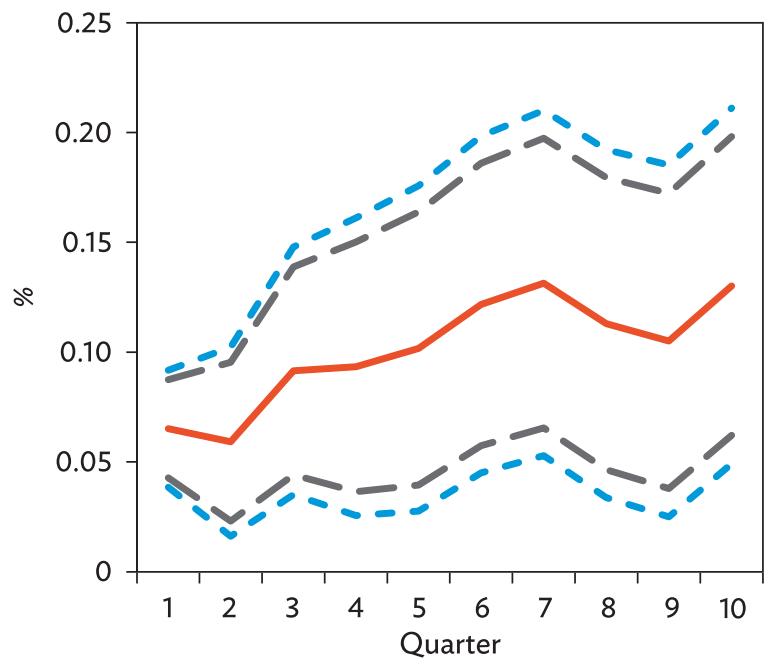

b. Linear and Quadratic Trend-Upturn

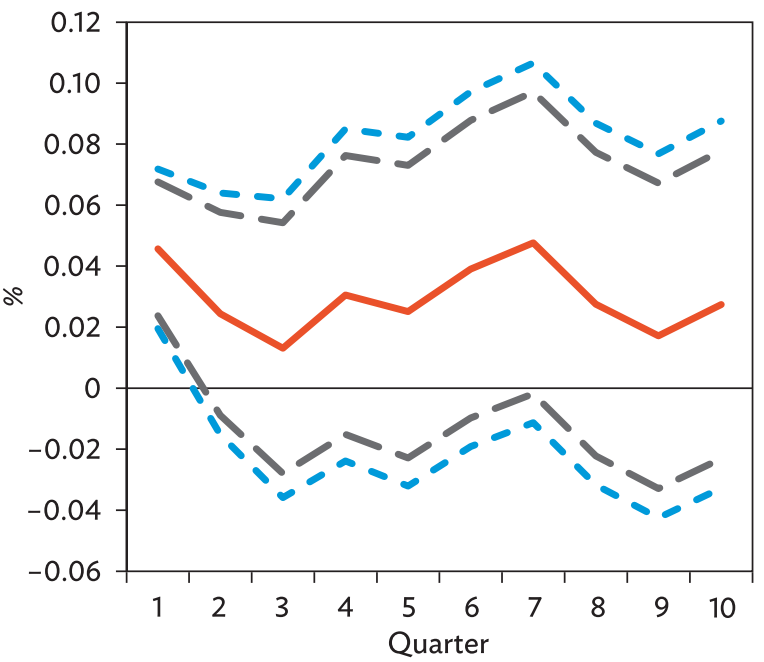

d. Quadratic Trend-Upturn

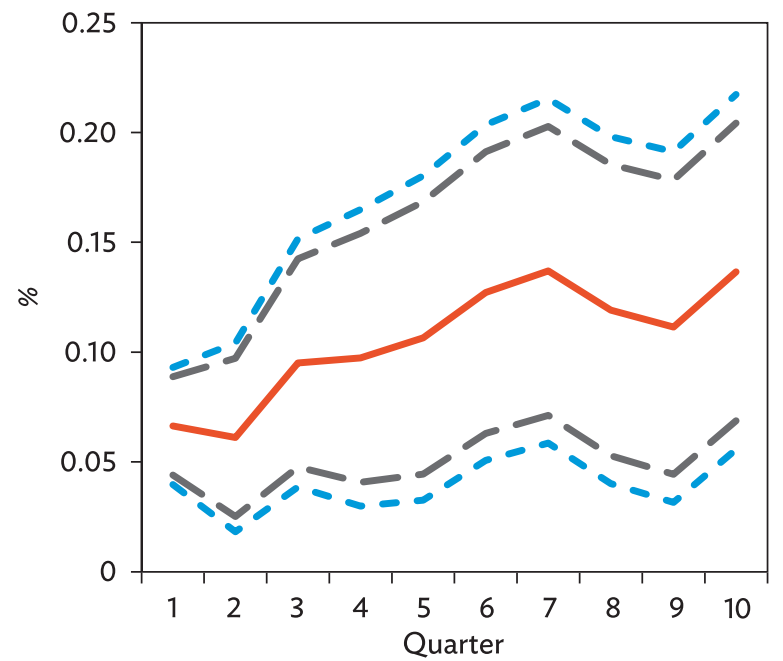

- - IRF bands at $5 \%$ level of significance

- IRF bands at $10 \%$ level of significance

Impulse response

IRF = impulse response function.

Source: Authors' estimation. 
Figure A2.7: Economic Cycle-Tax

a. Linear and Quadratic Trend-Downturn

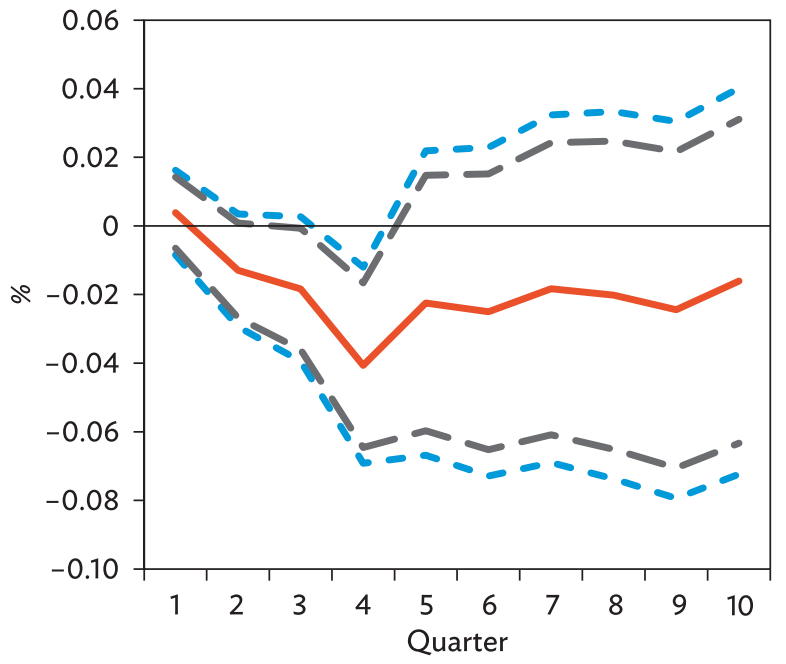

c. Quadratic Trend-Downturn

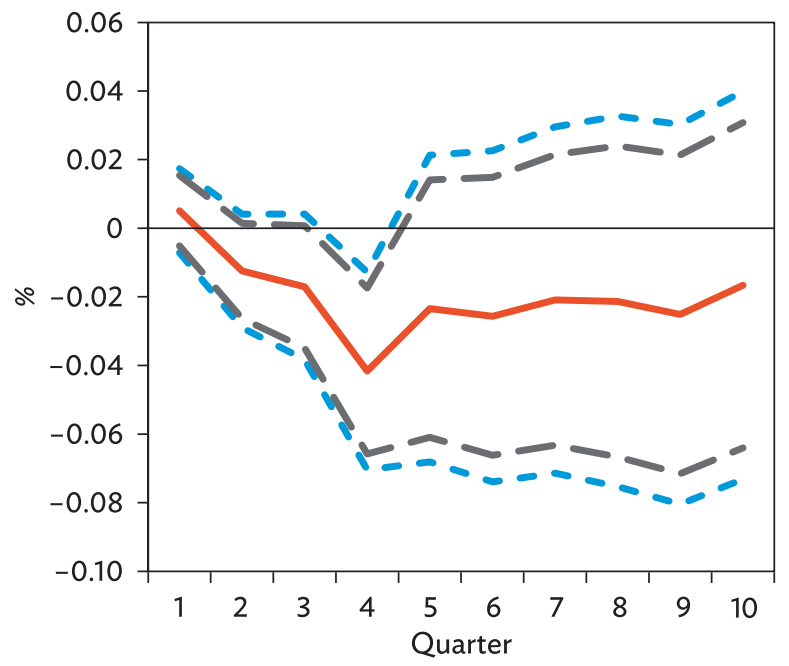

- - IRF bands at $5 \%$ level of significance

- IRF bands at $10 \%$ level of significance

IRF = impulse response function.

Source: Authors' estimation. b. Linear and Quadratic Trend-Upturn

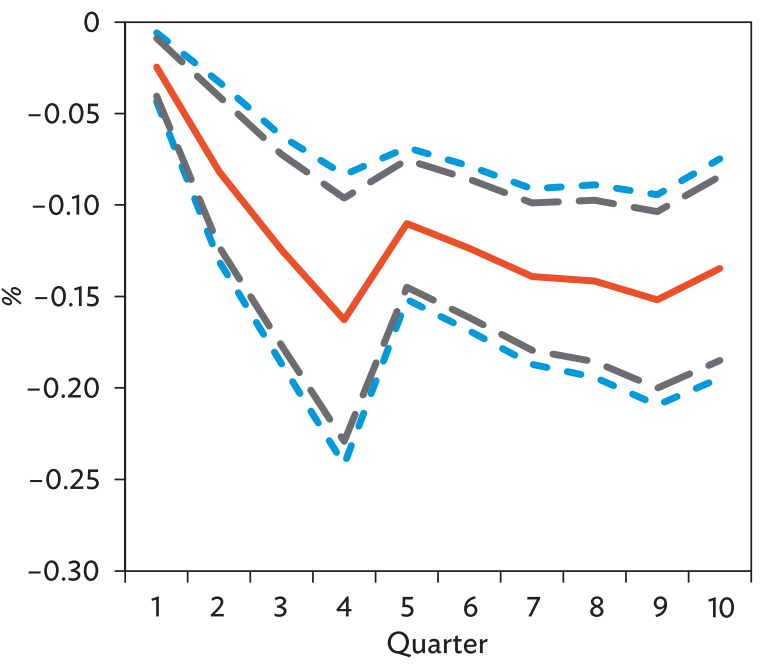

d. Quadratic Trend-Upturn

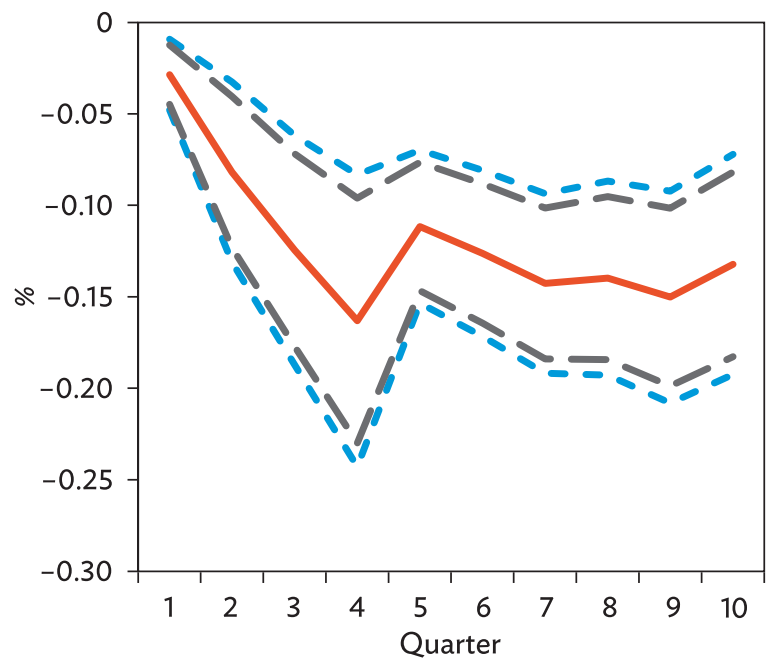

Impulse response 


\section{Figure A2.8: Monetary Policy-Government Spending}

a. Linear and Quadratic TrendAccommodative

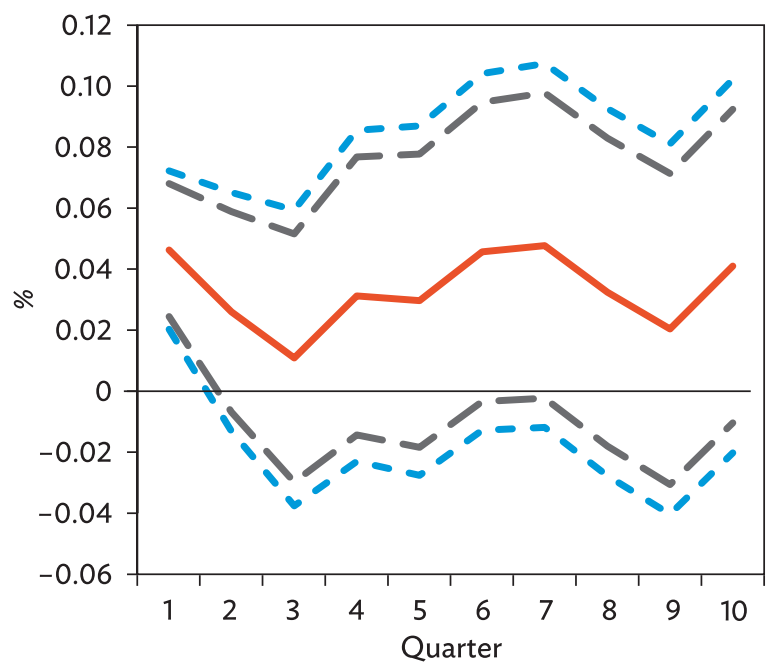

c. Quadratic Trend-Accommodative

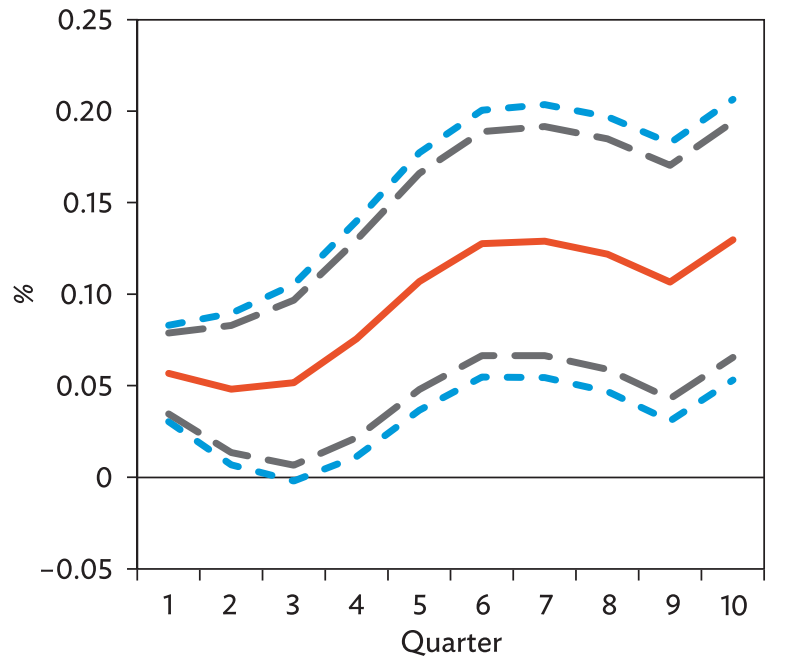

b. Linear and Quadratic TrendContradictory

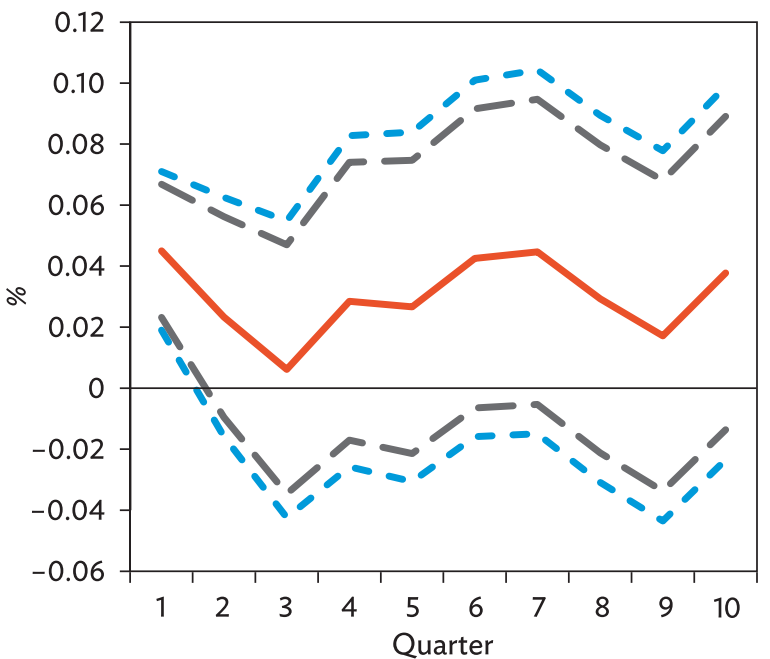

d. Quadratic Trend-Contradictory

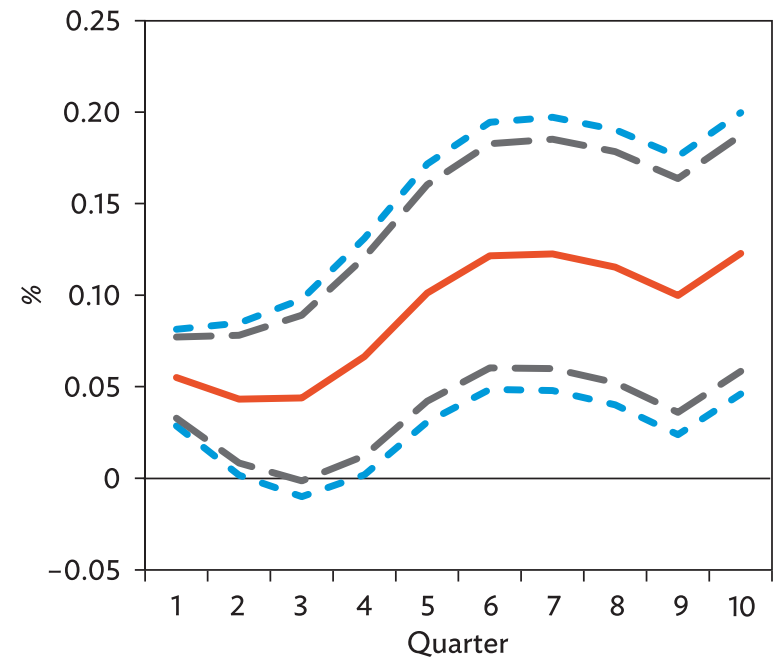

- - IRF bands at $5 \%$ level of significance

- IRF bands at $10 \%$ level of significance

Impulse response

$I R F=$ impulse response function.

Source: Authors' estimation. 


\section{Figure A2.9: Monetary Policy-Tax}

a. Linear and Quadratic TrendAccommodative

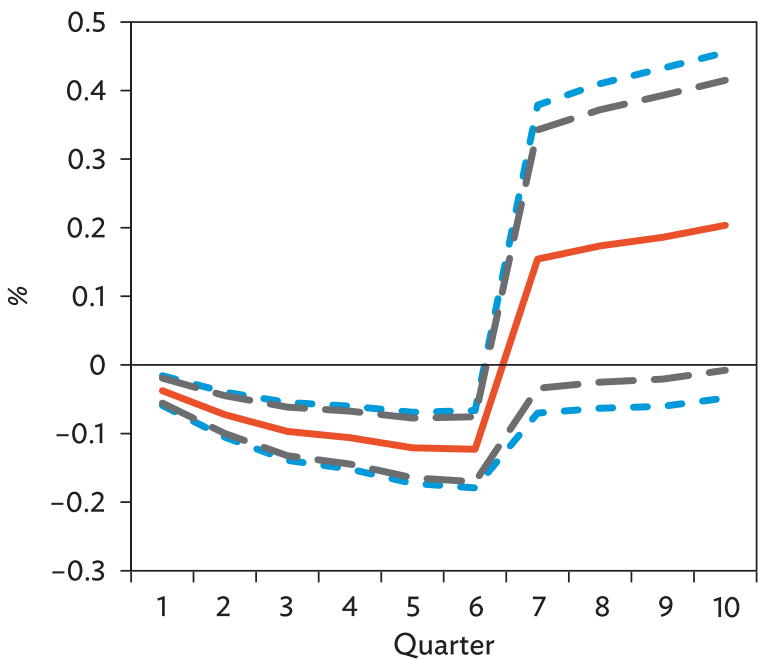

c. Quadratic Trend-Accommodative

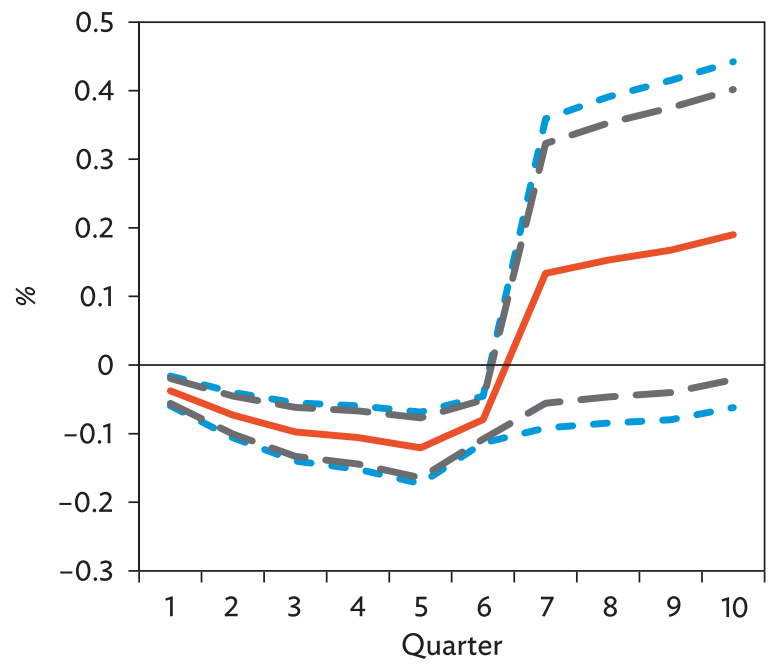

- IRF bands at $5 \%$ level of significance

- IRF bands at $10 \%$ level of significance b. Linear and Quadratic TrendContradictory

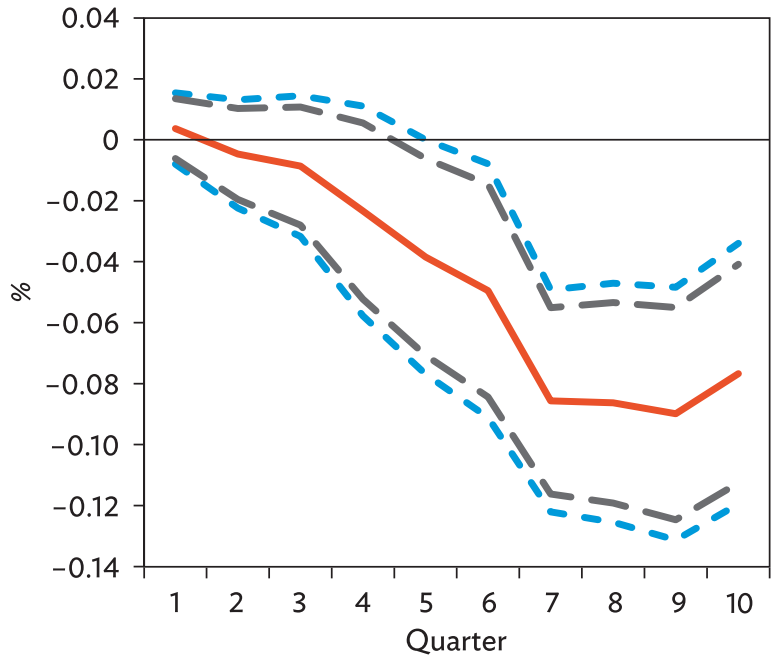

d. Quadratic Trend-Contradictory

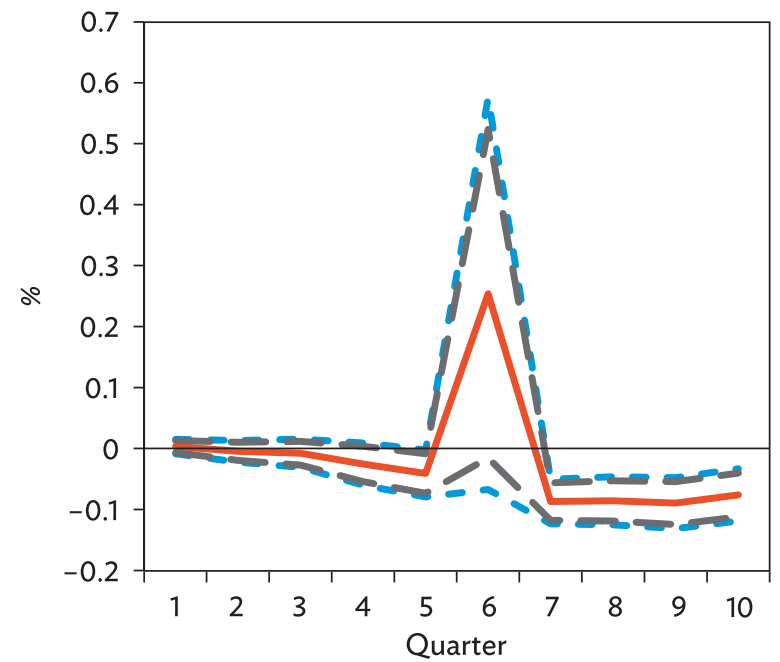

Impulse response

$\mathrm{IRF}=$ impulse response function.

Source: Authors' estimation. 


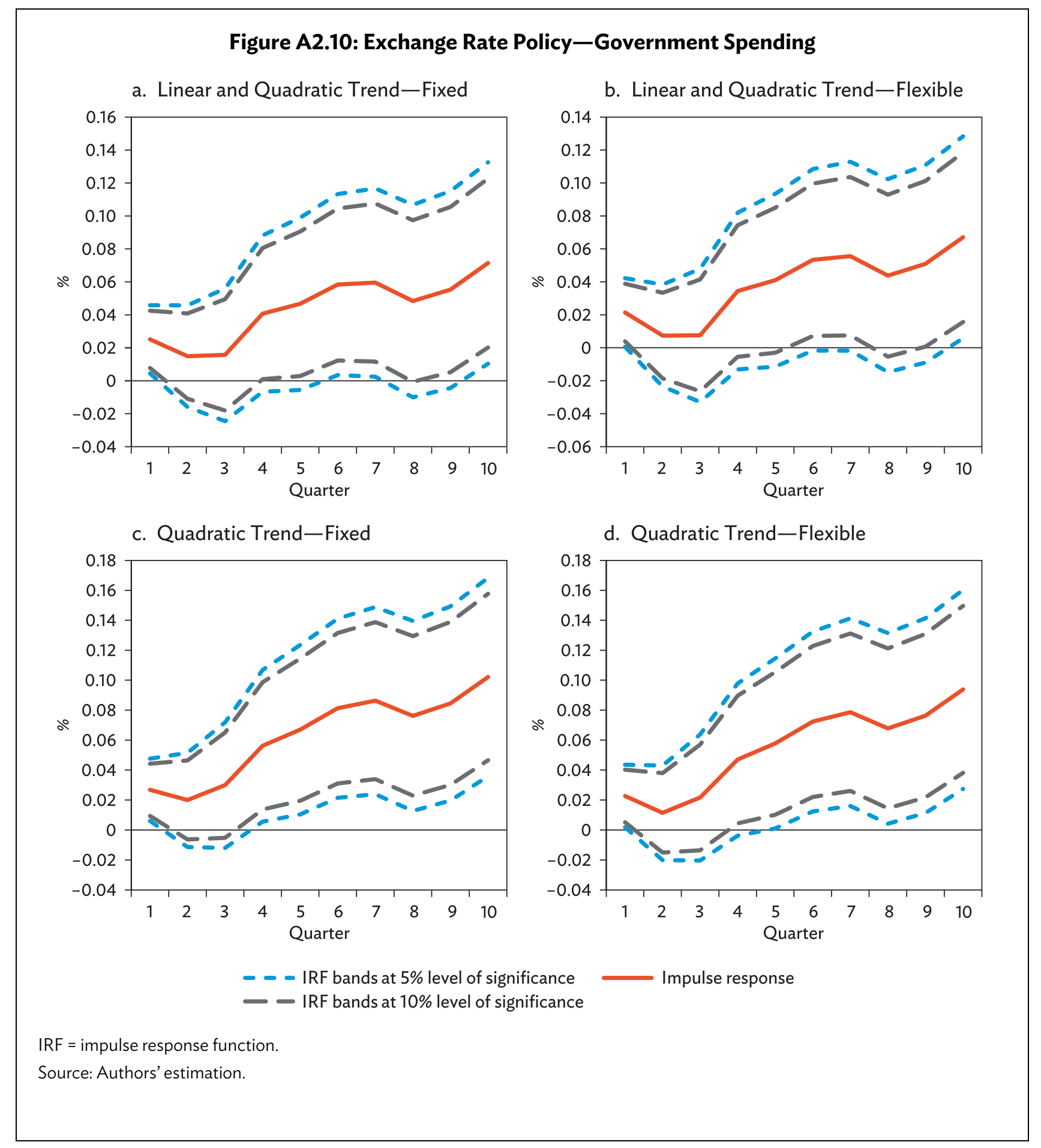




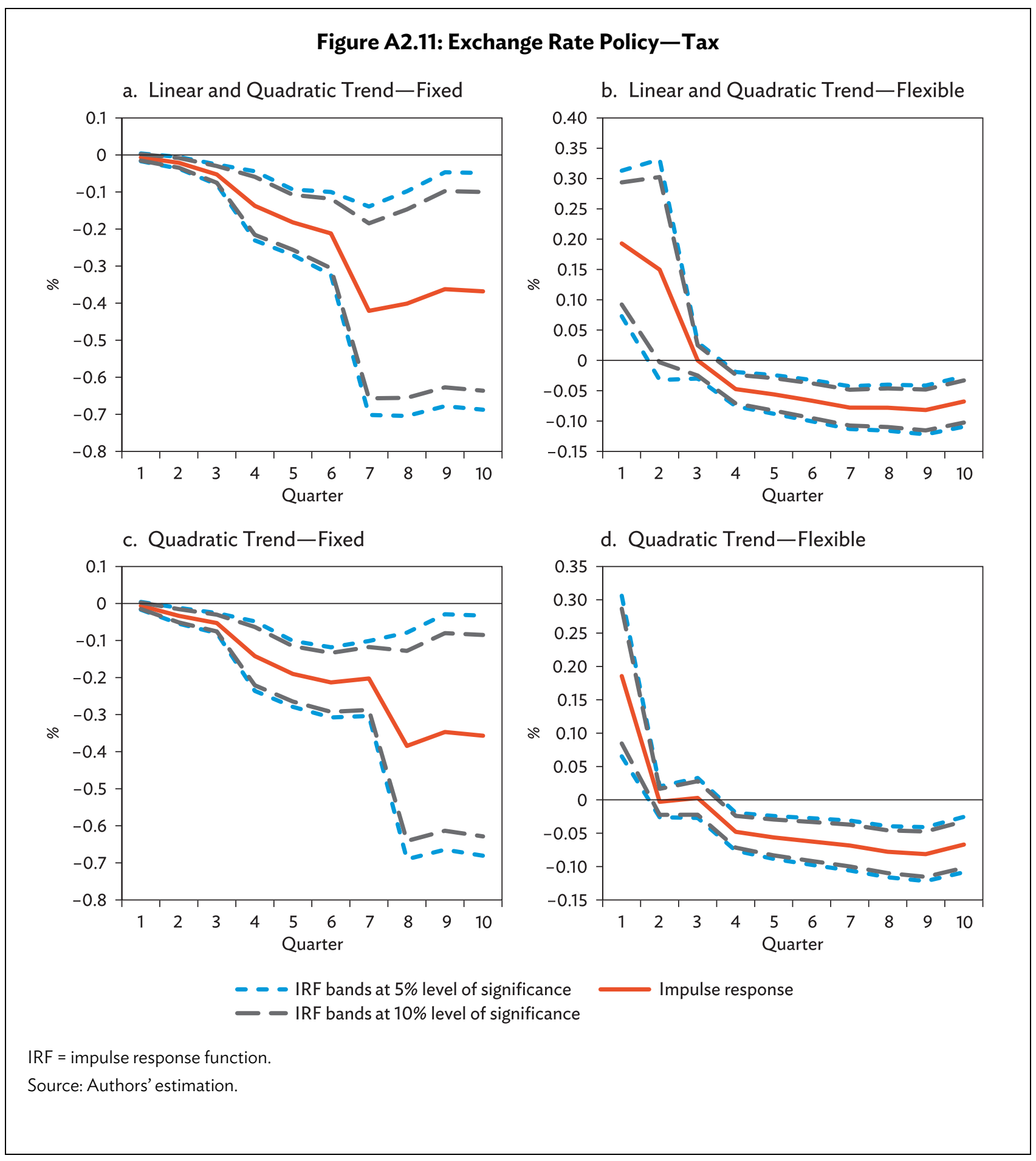




\section{REFERENCES}

Alloza, M., P. Burriel, and J. J. Pérez. 2018. Fiscal Policies in the Euro Area: Revisiting the Size of Spillovers. Banco de España Working Paper Series. No. 1820. Madrid: Banco de España.

Asian Development Bank (ADB). ADB COVID-19 Policy Database. https://covid19policy.adb.org.

Barro, R. J. 1996. Reflections on Ricardian Equivalence. NBER Working Paper Series. No. 5502. Massachusetts: National Bureau of Economic Research.

Batini, N., L. Eyraud, L. Forni, and A. Weber. 2014. Fiscal Multipliers: Size, Determinants, and Use in Macroeconomic Projections. IMF Technical Notes and Manuals. No. 2014/04. Washington, DC: International Monetary Fund.

Baum, A. and G. B. Koester. 2011. The Impact of Fiscal Policy on Economic Activity over the Business Cycle: Evidence from a Threshold VAR Analysis. Economic Studies Discussion Paper Series. No. 1. Frankfurt: Deutsche Bundesbank.

Blanchard, O. and D. Leigh. 2013. Growth Forecast Errors and Fiscal Multipliers. IMF Working Paper. No. 13/1. Washington, DC: International Monetary Fund.

Blanchard, O. and R. Perotti. 2002. An Empirical Characterization of the Dynamic Effects of Changes in Government Spending and Taxes on Output. Quarterly Journal of Economics.117 (4). pp. 1329-1368.

Christiano, L., M. Eichenbaum, and S. Rebelo. 2011. When Is the Government Spending Multiplier Large? Journal of Political Economy. 119 (1). pp. 78-121.

Cloyne, J. S., Ò. Jordà, and A. M. Taylor. 2020. Decomposing the Fiscal Multiplier. NBER Working Paper Series. No. 26939. Massachusetts: National Bureau of Economic Research.

David, A. C. 2017. Fiscal Policy Effectiveness in a Small Open Economy: Estimates of Tax and Spending Multipliers in Paraguay. IMF Working Paper. No. 17/63. Washington, DC: International Monetary Fund.

Elkhdari, M., M. Souissi, and A. Jewell. 2018. Empirical Estimation of Fiscal Multipliers in MENA OilExporting Countries with an Application to Algeria. IMF Working Paper. No. 18/124. Washington, DC: International Monetary Fund.

Farhi, E. and I. Werning. 2016. Fiscal Multipliers: Liquidity Traps and Currency Unions. In J. B. Taylor and H. Uhlig, eds. Handbook of Macroeconomics. Vol. 2B. Amsterdam: Elsevier B.V.

Ferraresi, T., A. Roventini, and G. Fagiolo. 2014. Fiscal Policies and Credit Regimes: A TVAR Approach. https://papers.ssrn.com/sol3/papers.cfm?abstract_id=2211105.

Gechart, S. and R. Mentges. 2017. Financial Cycles and Fiscal Multipliers. FMM Working Paper. No. 042017. Düsseldorf: IMK at the Hans Boeckler Foundation, Macroeconomic Policy Institute. 
Hepburn, C., B. O'Callaghan, N. Stern, J. Stiglitz, and D. Zenghelis. 2020. Will COVID-19 Fiscal Recovery Packages Accelerate or Retard Progress on Climate Change? Oxford Review of Economic Policy. 36 (S1). pp. S359-S381.

Jordà, Ò. 2005. Estimation and Inference of Impulse Responses by Local Projections. American Economic Review. 95 (1). pp. 161-182.

Plagborg-Moller, M. and C. K. Wolf. 2021. Local Projections and VARs Estimate the Same Impulse Responses. Econometrica. 89 (2). pp. 955-980.

Rafiq, S. and A. Zeufack. 2012. Fiscal Multipliers over the Growth Cycle: Evidence from Malaysia. Policy Research Working Paper. No. WPS 5982. Washington, DC: World Bank.

Ramey, V. A. 2019. Ten Years After the Financial Crisis: What Have We Learned from the Renaissance in Fiscal Research? The Journal of Economic Perspectives. 33 (2). pp. 89-114.

Ramey, V. A. and S. Zubairy. 2018. Government Spending Multipliers in Good Times and in Bad: Evidence from US Historical Data. Journal of Political Economy. 126 (2). pp. 850-901.

Reichling, F. and C. Whalen. 2012. Assessing the Short-Term Effects on Output of Changes in Federal Fiscal Policies. CBO Working Paper. No. 2012-08. Washington, DC: Congressional Budget Office.

Schwarz, G. E. 1978. Estimating the Dimension of a Model. Annals of Statistics. 6 (2). pp. 461-464.

Shaheen, R. and P. Turner. 2020. Fiscal Multipliers and the Level of Economic Activity: A Structural Threshold VAR Model for the UK. Applied Economics. 52 (17). pp. 1857-1865.

Tang, H. C., P. Liu, and E. C. Cheung. 2010. Changing Impact of Fiscal Policy on Selected ASEAN Countries. ADB Working Paper Series on Regional Economic Integration. No. 70. Manila: Asian Development Bank.

United Nations Department of Economic and Social Affairs, Population Division (UN DESA). 2019. World Population Prospects 2019. Online Edition. https://population.un.org/wpp/.

Wang, X. and Y. Wen. 2013. Is Government Spending a Free Lunch? - Evidence from China. Federal Reserve Bank of St. Louis Working Paper Series. No. 2013-013A. St. Louis: US Federal Reserve Bank.

Whalen, C. J. and F. Reichling. 2015. The Fiscal Multiplier and Economic Policy Analysis in the United States. US Congressional Budget Office Working Paper. No. 2015-02. Washington, DC: US Congressional Budget Office. https://www.cbo.gov/sites/default/files/112th-congress-2011-2012/workingpaper/ WorkingPaper2012-08-Effects_of_Fiscal_Policies_1.pdf.

Woodford, M. 2010. Simple Analytics of the Government Expenditure Multiplier. CEPR Discussion Paper. No. DP7704. London: Centre for Economic Policy Research. 


\section{Estimating Fiscal Multipliers in Selected Asian Economies}

The surge of the coronavirus disease (COVID-19) pandemic has driven countries worldwide to launch substantial stimulus packages to support economic recovery. This paper estimates effects of fiscal measures on output using data from 2000 to 2019 for a panel of nine developing Asian economies and a vector autoregression model. Results show that (i) the 4-quarter and 8-quarter cumulative fiscal multipliers for general government spending range between 0.73 and 0.88 in baselines, in line with recent estimates for developed countries but larger than those for developing countries; (ii) government spending is more effective than tax cuts in boosting the economy; and (iii) an accommodative monetary policy regime can make fiscal measures more effective.

\section{About the Asian Development Bank}

ADB is committed to achieving a prosperous, inclusive, resilient, and sustainable Asia and the Pacific, while sustaining its efforts to eradicate extreme poverty. Established in 1966, it is owned by 68 members -49 from the region. Its main instruments for helping its developing member countries are policy dialogue, loans, equity investments, guarantees, grants, and technical assistance. 